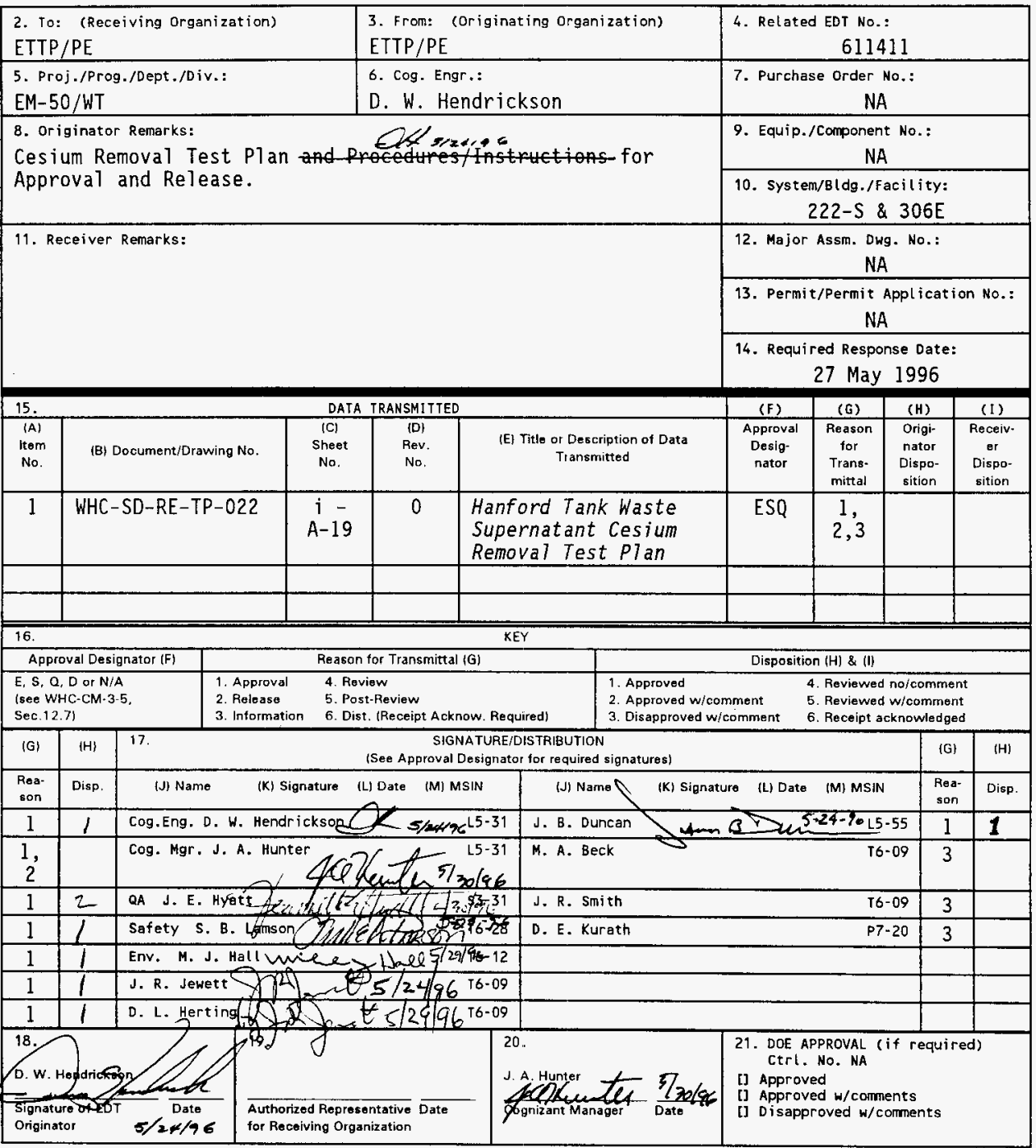

BD-7400-172-2(04/94) GEF097 


\title{
Hanford Tank Waste Supernatant Cesium Removal Test Plan
}

\author{
D. W. Hendrickson
}

J. B. Duncan

Westinghouse Hanford Company, Richland, WA 99352

U.S. Department of Energy Contract DE-AC06-87RL10930

EDT/ECN: $611413 \quad$ UC: 2020

Org Code: 8 A400 Charge Code: H2GA2

B\&R Code: EW4010000 Total Pages: 55

Key Words: Hanford, Tank Waste, DSSF, Cesium, Ion Exchange, Radioactive, Resorcinol-Formaldehyde, Crystalline Silicotitanate

Abstract: This document provides the test plan for the preparation and conduct of a cesium removal test using Hanford DSSF supernatant liquor from tank 241-AW-101 in a bench-scale column. Cesium sorbents to be tested include resorcinol-formaldehyde resin and crystalline silicotitanate.

TRADEMARK DISCLAIMER. Reference herein to any specific commercial product, process, or service by trade name, trademark, manufacturer, or otherwise, does not necessarily constitute or imply its endorsement, recommendation, or favoring by the United States Government or any agency thereof or its contractors or subcontractors.

Printed in the United States of America. To obtain copies of this document, contact: WHC/BCS Document Control Services, P.O. Box 1970, Mailstop H6-08, Richland WA 99352, Phone (509) 372-2420; fax (509) 376-4989.
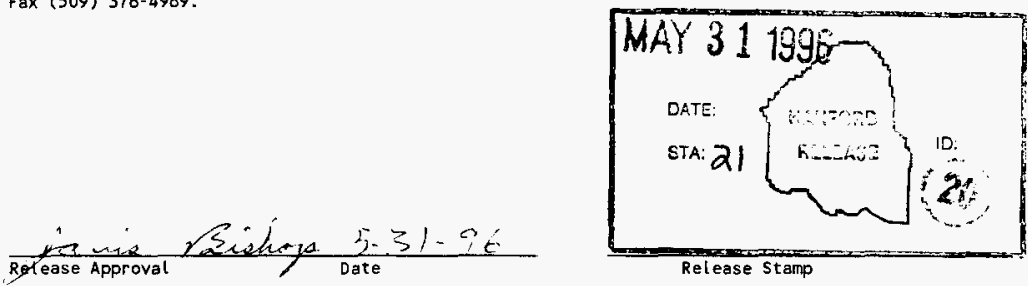

\section{Approved for Public Release}


WHC-SD-RE-TP-022, Rev. 0

THIS PAGE INTENTIONALLY LEFT BLANK 
1.0 INTRODUCTION $\ldots \ldots \ldots \ldots \ldots \ldots \ldots \ldots \ldots \ldots \ldots \ldots \ldots \ldots \ldots$

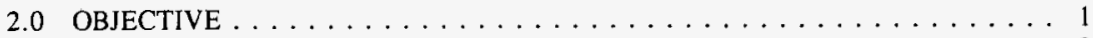

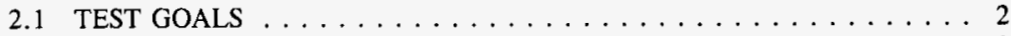

2.2 TEST CRITERIA REQUIREMENTS $\ldots \ldots \ldots \ldots \ldots \ldots \ldots \ldots$

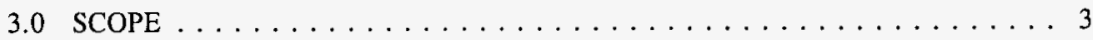

4.0 DESCRIPTION OF TEST $\ldots \ldots \ldots \ldots \ldots \ldots \ldots \ldots \ldots \ldots \ldots$

4.1 TEST ITEMS $\ldots \ldots \ldots \ldots \ldots \ldots \ldots \ldots \ldots \ldots$

4.1 .1 Waste Feed ................... 6

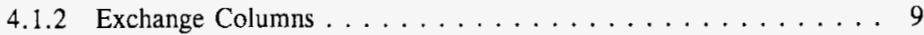

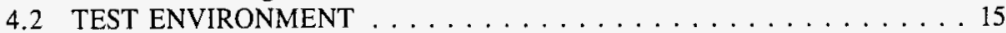

4.3 EQUIPMENT AND FACILITIES $\ldots \ldots \ldots \ldots \ldots \ldots \ldots \ldots$

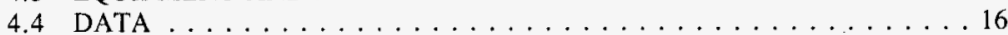

4.5 CRITERIA/CONSTRAINTS $\ldots \ldots \ldots \ldots \ldots \ldots \ldots \ldots$

4.6 WASTE MANAGEMENT AND DISPOSAL $\ldots \ldots \ldots \ldots \ldots$

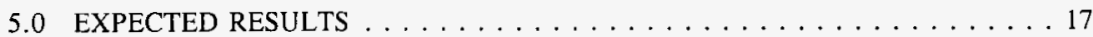

6.0 TEST PROCEDURE $\ldots \ldots \ldots \ldots \ldots \ldots \ldots \ldots \ldots \ldots \ldots \ldots \ldots \ldots$

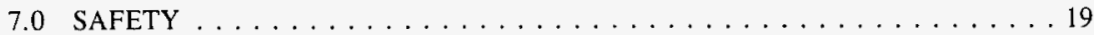

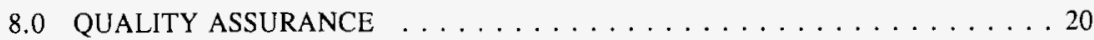

9.0 ORGANIZATION AND FUNCTION RESPONSIBILITIES . . . . . . . . 21

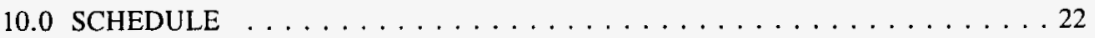

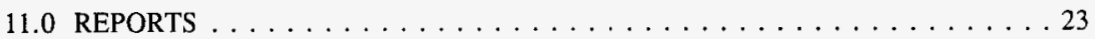

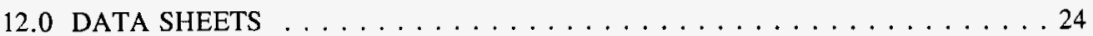

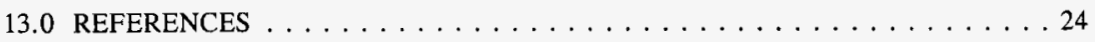




\section{LIST OF APPENDICES}

A: Sample and Material Dose Analyses $\ldots \ldots \ldots \ldots \ldots \ldots \ldots$ A-i

\section{LIST OF FIGURES}

PAGE

Figure 1: Bench-Scale Cesium Exchange Flows and Instrumentation . . . . . . . . 4

Figure 2: Primary $\beta / \gamma$ Activity Following the Cesium Extraction . . . . . . . 12

Figure 3: Primary $\beta / \gamma$ Signal Separation . . . . . . . . . . . . . . 12

Figure 4: Condensation Polymerization Synthesis of Phenol-Formaldehyde (Harland 1994) . . . . . . . . . . . . . . . . . . . . . . . . . . . . . 13

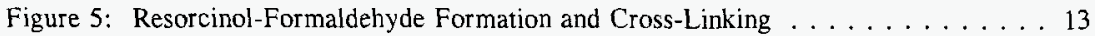

Figure 6: Cesium Removal Task Schedule . . . . . . . . . . . . . 23

\section{LIST OF TABLES}

PAGE

Table 1: Historic Characterization of 241-AW-101 Supernatant Liquor . . . . . . . 7

Table 2: Counter-Ion and Decay Product Crystal Radii . . . . . . . . . . . . 11

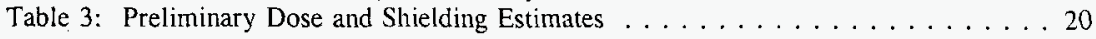

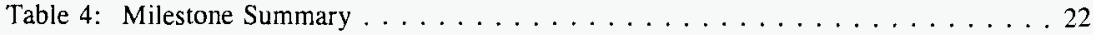


WHC-SD-RE-TP-022, Rev. 0

ABBREVIATIONS
Becquerel, one disintegration per second
Curie, $3.7 \times 10^{10}$ Becquerel
Crystalline Silicotitanate
Decontamination Factor
United States Department of Energy
Double-Shell Slurry Feed
Laboratory information management system
Low Level Waste
Nuclear Regulatory Commission
Office of Science and Technology
Battelle Pacific Northwest National Laboratory
Quality Assurance Project Plan
Resorcinol-Formaldehyde ion exchange resin
Tank Focus Area
Total Organic Carbon
Transuranic, atomic number greater than 92
Tank Waste Remediation System
Westinghouse Hanford Company
Barium, metastable isotope 137
Cesium, isotope 137


WHC-SD-RE-TP-022, Rev. 0

THIS PAGE INTENTIONALLY LEFT BLANK 
WHC-SD-RE-TP-022, Rev. 0

\section{Hanford Tank Waste Supernatant Cesium Removal Test Plan}

\subsection{INTRODUCTION}

Cesium-137 $\left({ }^{137} \mathrm{Cs}\right)$ is a primary radiation source in the dissolved tank waste at the Hanford Site. ${ }^{137} \mathrm{Cs}$ removal from the waste can reduce the hazard and waste classification (NRC 1989) of the low level waste and reduce treatment and disposal costs.

Several cesium removal sorbents have been developed by private industry and the U.S. Department of Energy's (DOE) Office of Science and Technology (OTS) [EM-50] for the removal of cesium from the radioactive tank wastes located at various DOE facilities. Although there have been a number of batch tests using Hanford tank wastes and several column tests using simulated Hanford tank wastes or actual wastes from other DOE sites, little data exists on the use of these sorbents in column systems with actual Hanford Site tank wastes.

Hanford Site's Tank Waste Remediation System (TWRS) organization has indicated that column-flow tests using these sorbents with actual waste need to be performed to verify the applicability of the simulant data. These tests may also identify as of yet unknown problems or interferences when processing actual wastes under actual conditions. (Penwell et al. 1994)

This work is funded by the DOE OST Tanks Focus Area under Technology Task Plan RL46WT41 Cesium Removal Tests Using Hanford DSSF Supernatants.

\subsection{OBJECTIVE}

The overall goal of this task (test and its analysis) is to qualify a cesium sorbent which will meet the cesium removal requirements of the Hanford privatization initiative (DOE 1996). The specific objectives of this task to meet the goal are through test conduct and through analysis:

The test conduct objective is to provide samples and operational data to determine the column distribution ratio (lambda, $\lambda$ ) of each sorbent when used with Hanford Double-Shell Slurry Feed (DSSF) supernatant liquor in a benchscale, column system. The column system will be operated with continuous cesium loading until breakthrough is noticeable and is increasing at a constant logarithmic rate. This will increase the validity of applying the results of previous batch and simulant tests towards the selection and design of a cesium removal system with Hanford Site tank waste. 
WHC-SD-RE-TP-022, Rev. 0

The analytical objective is to determine whether each sorbent's cesium selectivity is high enough to reduce the ${ }^{137} \mathrm{Cs}$ concentration of LLW feed below the process exit limit of $3.7 \times 10^{10} \mathrm{~Bq}{ }^{137} \mathrm{Cs} / \mathrm{m}^{3}\left(1 \mathrm{Ci} / \mathrm{m}^{3}\right)$ of $\mathrm{LLW}$ form (DOE 1996) required by the Hanford privatization initiative. Effluent ${ }^{137} \mathrm{Cs}$ concentrations from this column test will be measured to confirm they are below the process exit limit. Observations throughout the test may provide process data on waste/exchanger interactions, fouling, and overall loading on the sorbents.

A programmatic (EM-50) objective related to this test is to make a cesium depleted effluent available to Battelle Pacific Northwest National Laboratory (PNNL) for technetium removal studies and to other Environmental Management tasks. A residual ${ }^{137} \mathrm{Cs}$ concentration of approximately $9.25 \times 10^{5} \mathrm{~Bq} / \mathrm{L}(25 \mu \mathrm{Ci} / \mathrm{L})[0.01 \%$ of feed concentrations] is anticipated to allow follow-on technetium removal tests to be performed in a hood rather than a hotcell.

The two cesium sorbents which will be used are crystalline silicotitanate (CST) and Resorcinol-Formaldehyde (R-F). The DSSF waste which is planned for use in this test is supernatant liquor sampled from Hanford Tank 241-AW-101.

\subsection{TEST GOALS}

To satisfactorily complete the objectives of the test plan, several test conduct goals must be met. The test goals are:

- Assembly, acceptance testing and placement of the sorption equipment into the hot cell.

- Hot cell receipt, dilution, and solids removal from the tank waste feed for the sorption.

- Waste cesium ion exchange using R-F, collecting samples and data to breakthrough followed by flush and elution of the exchange material.

- Waste cesium removal using CST, collecting samples and data through breakthrough followed by flush and elution, if necessary, of the sorption material.

- Appropriate and safe waste and material disposition.

\subsection{TEST CRITERIA REQUIREMENTS}

The assembly, acceptance testing and placement criterion of the test will be considered complete when all sorption, sampling, and detection equipment has been acquired, 
WHC-SD-RE-TP-022, Rev. 0

assembled, leak tested, calibrated, and placed into the $1 \mathrm{~F}$ hot cell with flow path and valve operation confirmed.

The second criterion will be complete when the volume of radioactive supernatant liquor from Hanford tank 241-AW-101 is transferred from the 11A1A hot cell to the $1 \mathrm{~F}$ hot cell, diluted, mixed, settled and centrifuged for solids removal, stored in appropriate feed tanks, and sampled and analyzed for initial feed characterization confirmation.

The third criterion will be considered complete when the R-F resin column has been placed in the test apparatus (in concert with the R-F guard column), prepared for contact, contacted with the waste feed flow to breakthrough $\left(50-70 \%\right.$ effluent/feed concentration, $\left.\mathrm{C} / \mathrm{C}_{0}{ }^{137} \mathrm{Cs}\right)$, flushed, and eluted. Sample and data acquisition is required during the cesium removal. Sample analysis is required during or following the cesium removal.

The fourth criterion will be considered complete when the CST column has been placed in the test apparatus (in concert with the CST guard column), prepared for contact, contacted with the waste feed flow through breakthrough $\left(50-70 \%\right.$ effluent/feed concentration, $\mathrm{C} / \mathrm{C}_{u}$ ${ }^{137} \mathrm{Cs}$ ) and the system and sorption material flushed. Sample and data acquisition is required during the cesium removal. Sample analysis is required during or following the cesium removal.

The final criterion will be considered complete when waste feed materials, contaminated equipment, effluents, eluates, flushes, and exchange materials have been appropriately characterized and are dispositioned for appropriate disposal or reuse.

\subsection{SCOPE}

The scope of this test plan includes the acceptance and process testing of a bench-scale cesium exchange equipment array with radioactive Hanford tank waste feed material. The acceptance and process testing will include: waste feed analysis and preparation, exchange bed preparation, exchange, the acquisition and analysis of samples and data from the exchange, exchange bed flush and elution as necessary, and waste and material disposition. Physical property, chemical, and radiochemical analysis of sample materials, although directed by this plan, are within the scope of routine sample analysis and not preceduralized herein.

This test plan is to be executed under the direction of the Westinghouse Hanford Company (WHC) Projects and Site Services/Engineering Testing and Technology Projects/Process Engineering (ETT/PE) staff in coordination with and by the staff of the WHC Tank Waste Remediation System (TWRS) Characterization Project/Analytical Services/222-S Analytical 
WHC-SD-RE-TP-022, Rev. 0

Operations/ Chemistry and Statistics section. The test work is to be conducted within the facilities and hot cells of the 222-S Analytical Laboratory.

\subsection{DESCRIPTION OF TEST}

For this cesium ion exchange test, a test apparatus will be constructed, functionally tested, then placed in a hot cell within the 222-S Laboratory. Approximately four and one-half liters of drainable DSSF supernatant liquor from Hanford Tank 241-AW-101 will be acquired through the sampling efforts of the TWRS Characterization Project at Hanford (Benar 1996) and will be placed in the hot cell with the test apparatus. The DSSF supernatant liquor will be diluted with water to a concentration target of five molar sodium, mixed, settled and decanted to remove particles, and then placed in the feed tank(s) to be used as the feed for both column tests.

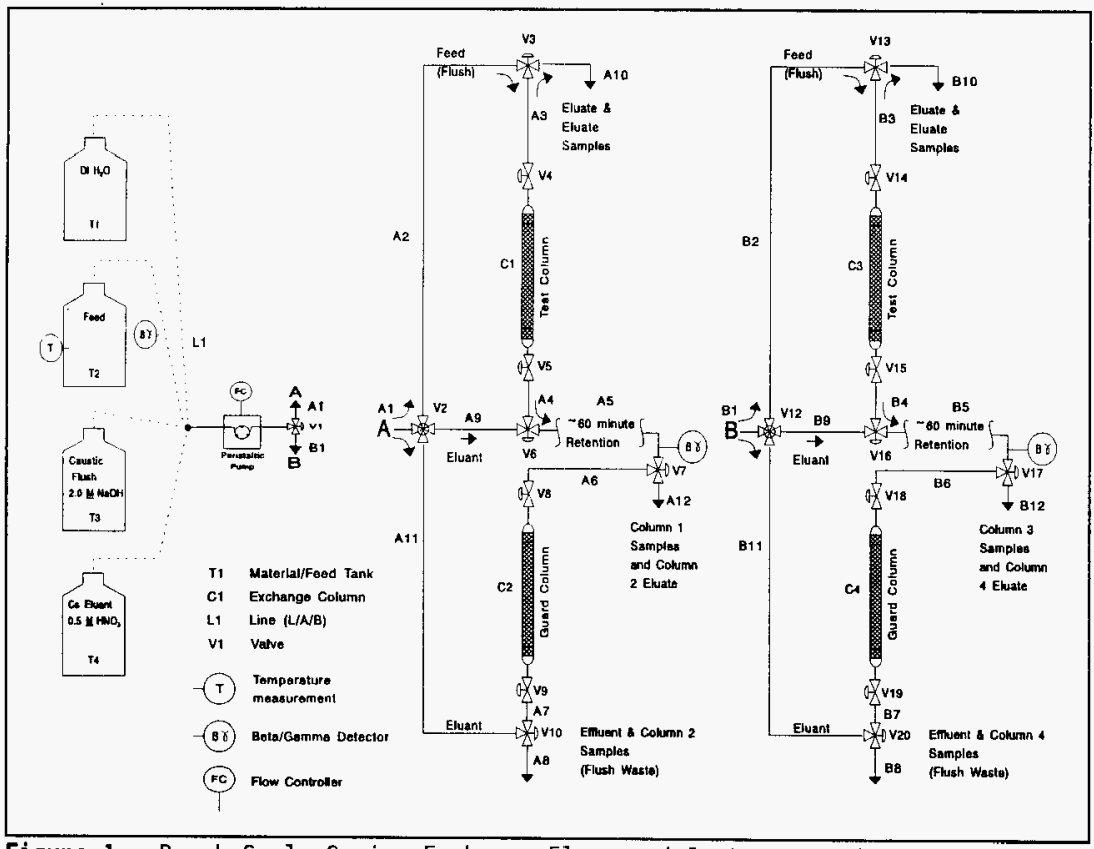

Figure 1: Bench-Scale Cestum Exchange Flows and Instrumentation 
WHC-SD-RE-TP-022, Rev. 0

The test apparatus will contain two test columns and two scavenging (guard) columns. One test column will be packed with crystalline silicotitanate (CST) and the other with Resorcinol-Formaldehyde (R-F). The scavenging column in each subassembly will be packed with the same materials as the test column and will be used to reduce any cesium remaining in the effluent. The effluent is intended to be provided to subsequent Tanks Focus Area (TFA) tasks which will require the material for technetium (Tc) removal studies. A sketch of the process flows and instrumentation is provided in Figure 1.

During the loading phase of the column test, the feed solution will be pumped from the feed tank downward through a test column of cesium sorbent. The feed temperatures will be recorded at the beginning, during, and after the test. The effluent will be monitored for cesium breakthrough and will be sampled periodically. Samples will also be taken of the feed and the eluate. Sample analysis, as available, will be performed to determine the concentration of analytes to which the cesium ion exchange and vitrification processes are sensitive. These analytes include: cesium-137, total cesium, strontium, sodium, potassium, rubidium, aluminum, phosphorus (for phosphate), chromium, and iron as well as the $\mathrm{pH}$ of the sample.

After cesium breakthrough is detected in the R-F test column, the R-F column will be flushed and the cesium will be eluted from the R-F. After cesium breakthrough is detected in the CST test column, the CST column will be flushed and drained, removed from the system, and made available for shipping to another lab for analysis or digested, sampled, and disposed. Initial plans for the cesium sorbent materials are in-cell digestion and disposal due to the high shielding requirements and limited capacity of manipulators and airlock tray entailed with removal from the hot cell (see § 7.0).

The performance of the sorbents in the removal of cesium from DSSF, and process considerations of such removal, will be evaluated and reported in a final report.

\subsection{TEST ITEMS}

The test items are the bed materials (CST and R-F) and the waste feed. The object of this test is to demonstrate the cesium selectivity, load capacity, and elution, as necessary, of CST and R-F using actual Hanford DSSF waste. In reporting the completion of this work, this information will be compared to related data gathered using simulants and will be used to validate the simulant data's use in the design of a cesium removal pretreatment process. 
WHC-SD-RE-TP-022, Rev. 0

\subsubsection{Waste Feed}

Aspects of consideration in the waste feed as a test item are the volume and source requirements, the prior knowledge of the waste, dilution capability, and additional estimates of impact of the waste source and history upon the test.

\subsubsection{Volumetric and Source Requirements}

The waste volume required for adequate demonstration of the performance of these columns is estimated to be four and one-half liters (to be diluted to approximately nine liters). This is based on 0.3 to 0.4 liter of waste for the R-F run and 3.1 to 4.7 liters for the CST run including breakthrough loss and conservative variability in breakthrough expectations.

The waste feed is to be a composite of drainable supernatant liquor from samples taken from Hanford Double-Shell tank 241-AW-101 during 1996 core drilling operations (begun February 14, 1996) (Benar 1996).

\section{1,1.2 Tank Characterization History}

Prior knowledge of the waste composition has been applied in preparing this test plan. In particular, sampling during generation (Hendrickson 1990), and sampling during 1990 with subsequent analysis (Welsh 1991), yielded the result that the supernatant liquor was homogeneous with regard to cesium, sodium, and potassium. A summary of the composition from these analyses, decayed to $06 / 01 / 96$, is presented in Table 1 . The contents of tank 241-AW-101 are miscellaneous facilities wastes of the 100,200,300, and 400 areas of the Hanford site which have been concentrated through low-temperature, low-pressure evaporation to a concentration of $10 \underline{\mathrm{M}}$ sodium.

This waste material has been chosen for the demonstration of cesium exchange for several reasons including the relatively high sodium, potassium, and hydroxide content. The potassium, at $1.07 \underline{\mathrm{M}}$, is considered very high and is anticipated to inhibit cesium sorption. TRU contaminants in the waste and their sorption must be considered for waste designation and appropriate disposal. In addition to the chemical characteristics this material is used as a source because of its availability with current sampling (Benar 1996) and anticipations that this waste material may be among those wastes initially dispositioned to a low-level waste vitrification facility.

\subsubsection{Dilution Capability and Requirements}

As described above, the waste feed is of approximately $10 \mathrm{M} \mathrm{Na}^{+}$and $5 \mathrm{M} \mathrm{OH}$. Performance of many ion exchange materials has been to shown to degrade rapidly at sodium and hydroxide concentrations approaching these values. In order to facilitate performance 
Table 1: Historic Characterization of 241-AW-101 Supernatant Liquor

\begin{tabular}{|c|c|c|c|c|c|}
\hline \multicolumn{6}{|c|}{ Tank 241-AW-101 DSSF Composition } \\
\hline \multicolumn{6}{|c|}{ Units: Molarity; $\mu \mathrm{Ci} / \mathrm{L}$ for radionuclides; others as noted } \\
\hline Analyte & Result & Analyte & Result & Analyte & Result \\
\hline$\overline{A g}$ & $3.09 \mathrm{E}-04$ & $\mathrm{Si}$ & $4.36 \mathrm{E}-03$ & ${ }^{3} \mathrm{H}$ & $5.08 \mathrm{E}+00$ \\
\hline $\mathrm{Al}$ & $1.03 \mathrm{E}+00$ & $\mathrm{Ti}$ & $9.88 \mathrm{E}-05$ & ${ }^{14} \mathrm{C}$ & $3.70 \mathrm{E}-01$ \\
\hline As & $1.33 \mathrm{E}-07$ & $\mathrm{U}(\mathrm{g} / \mathrm{L})$ & $9.39 \mathrm{E}-04$ & ${ }^{60} \mathrm{Co}$ & $1.37 \mathrm{E}+01$ \\
\hline $\mathrm{Ba}$ & $6.80 \mathrm{E}-05$ & $\mathrm{Zn}$ & $4.84 \mathrm{E}-03$ & ${ }^{79} \mathrm{Se}$ & $4.80 \mathrm{E}-01$ \\
\hline $\mathrm{Bi}$ & $5.79 \mathrm{E}-04$ & $\mathrm{Zr}$ & $5.54 \mathrm{E}-04$ & ${ }^{90} \mathrm{Sr}$ & 943 \\
\hline $\mathrm{Ca}$ & $8.26 \mathrm{E}-04$ & $\mathrm{CN}^{-}$ & $1.03 \mathrm{E}-03$ & ${ }^{94} \mathrm{Nb}$ & 68.20 \\
\hline $\mathrm{Cd}$ & $1.08 \mathrm{E}-05$ & $\mathrm{NH}_{4}^{+}$ & $1.45 \mathrm{E}-02$ & ${ }^{99} \mathrm{Tc}$ & 152.00 \\
\hline $\mathrm{Cr}$ & $3.09 \mathrm{E}-03$ & $\mathrm{CO}_{3}^{-2}$ & $2.05 \mathrm{E}-01$ & ${ }^{106} \mathrm{RuRh}$ & 68.22 \\
\hline $\mathrm{Cu}$ & $3.81 \mathrm{E}-04$ & $\mathrm{Cl}^{-}$ & $1.46 \mathrm{E}-01$ & ${ }^{129} \mathrm{I}$ & 0.3030 \\
\hline $\mathrm{Fe}$ & $7.86 \mathrm{E}-04$ & $\mathrm{~F}^{-}$ & 4.02 E-03 & ${ }^{134} \mathrm{Cs}$ & 212.43 \\
\hline $\mathrm{Hg}$ & $7.82 \mathrm{E}-07$ & $\mathrm{SO}_{4}^{-2}$ & $1.07 \mathrm{E}-02$ & ${ }^{137} \mathrm{Cs}$ & 454088 \\
\hline $\mathrm{K}$ & $1.07 \mathrm{E}+00$ & $\mathrm{NO}_{3}$ & $3.46 \overline{E+00}$ & ${ }^{237} \mathrm{~Np}$ & $2.16 E+00$ \\
\hline $\mathrm{Mg}$ & $2.16 \mathrm{E}-03$ & $\mathrm{NO}_{2}$ & $2.19 \mathrm{E}+00$ & ${ }^{239 / 240} \mathrm{Pu}$ & $1.14 \mathrm{E}+00$ \\
\hline $\mathrm{Mn}$ & $4.76 \mathrm{E}-04$ & $\mathrm{PO}_{4}{ }^{-3}$ & $2.22 \mathrm{E}-02$ & ${ }^{241} \mathrm{Am}$ & $1.19 \mathrm{E}+00$ \\
\hline Mo & $6.00 \mathrm{E}-04$ & $\mathrm{OH}^{-}$ & $5.07 \mathrm{E}+00$ & ${ }^{243} \mathrm{Cm}$ & $4.63 \mathrm{E}-02$ \\
\hline $\mathrm{Na}$ & $1.00 \mathrm{E}+01$ & TOC $(\mathrm{g} / \mathrm{L})$ & $2.46 \mathrm{E}+00$ & SPG & 1.56 \\
\hline $\mathrm{Pb}$ & $1.46 \mathrm{E}-03$ & TIC $(\mathrm{g} / \mathrm{L})$ & $2.46 \mathrm{E}+00$ & Volume (L) & 3826969 \\
\hline $\mathrm{Se}$ & $4.20 \mathrm{E}-07$ & & ed to & $06 / 01 / 96$ & \\
\hline
\end{tabular}

and minimize degradation of the exchange materials, the waste feed will be diluted to a target of approximately $5 \underline{\mathrm{M}} \mathrm{Na}$. The diluent, in prior work for similar wastes (Brown $e t$ al. 1995), was aqueous sodium hydroxide so that gibbsite $\left(\mathrm{Al}(\mathrm{OH})_{3}\right)$ precipitation would not occur $\left(\mathrm{OH}^{-}\right.$falling below $\left.\sim 2 \underline{\mathrm{M}}\right)$. Investigations of sodium aluminate, sodium sulfate, 
sodium carbonate, sodium nitrite, and sodium nitrate solubility (Barney 1976), as applied to this waste composition, indicate that each of these constituents would remain in solution at expected temperatures with direct dilution by water.

\subsubsection{Waste Composition Estimates}

Estimates of isotopic compositions, beyond those described in Table 1, must be made based upon fuel irradiation, decay, and contamination with essential materials. In the manner of Hendrickson and Conner (1994), the generation and decay of materials may be estimated with the aid of fuel irradiation calculations conducted with ORIGEN2 (Hedengren 1985). In an assumed case of $\mathrm{N}$-Reactor mixed fuel irradiated to $12 \% \mathrm{Pu}$, the existent ratio of ${ }^{134} \mathrm{Cs} /{ }^{137} \mathrm{Cs}$ may used to derive a fuel discharge date for the source of the waste. In this case, the 06.01/96 concentration ratio of these materials may be corrected to the estimated discharge date of April 15, 1975.

From this discharge date the ORIGEN2 fission product calculations (Hedengren 1985), may be used to estimate the fission product, decay, and ingrowth of ${ }^{133} \mathrm{Cs},{ }^{134} \mathrm{Cs},{ }^{135} \mathrm{Cs},{ }^{85} \mathrm{Rb}$, and ${ }^{87} \mathrm{Rb}$ in relation to the ${ }^{137} \mathrm{Cs}$ activity. Each of these must be considered for this ion exchange test because the cesium isotopes other than ${ }^{137} \mathrm{Cs}$ will equally compete for exchange sites and because the rubidium is expected to compete for the exchange sites.

Each of the stable rubidium isotopes described above must be estimated, as no chemical analyses of these species have historically been conducted. The ratio of these rubidium species is always changing as the ${ }^{85} \mathrm{Rb}$ is the stable daughter of ${ }^{85} \mathrm{Kr}$ on the 85 -isobar. The estimated concentrations of these rubidium isotopes in this waste are $105 \mu \mathrm{M}^{85} \mathrm{Rb}$ and $220 \mu \underline{\mathrm{M}}{ }^{87} \mathrm{Rb}$ (total $325 \mu \mathrm{M}$ ), with a resultant concentration ratio of $67.7 \%{ }^{87} \mathrm{Rb} / \mathrm{Rb}$. These values are consistent with recent tank waste isotopic analyses from tank 241-SY-101 and 241-SY-103 (Brown et al. 1995) wherein the ${ }^{87} \mathrm{Rb} / \mathrm{Rb}$ was $65 \%$ and $68.1 \%$, respectively.

Total cesium content must be estimated because some cesium is known to have been a contaminant in essential materials for operations (e.g. $\mathrm{NaOH}, \mathrm{NaNO}_{2}, \mathrm{NaNO}_{3}$ ). From the above fuel product ratios of cesium isotopes, the cesium present in the waste would be $67.2 \mu \underline{\mathrm{M}}{ }^{133} \mathrm{Cs}, 0.0012 \mu \underline{\mathrm{M}}{ }^{134} \mathrm{Cs}, 17.4 \mu \underline{\mathrm{M}}{ }^{135} \mathrm{Cs}$, and $38.3 \mu \underline{\mathrm{M}}{ }^{137} \mathrm{Cs}$ for a total concentration of $123 \mu \mathrm{M}$ Cs. Cesium contamination in the waste will have been in the form of ${ }^{133} \mathrm{Cs}$. An assumed contamination of $45 \mu \underline{\mathrm{M}}{ }^{133} \mathrm{Cs}$ would increase total cesium concentrations to $168 \mu \underline{\mathrm{M}}$ and reduce the ${ }^{137} \mathrm{Cs} / \mathrm{Cs}$ to $22.8 \%$. This ratio of ${ }^{137} \mathrm{Cs} / \mathrm{Cs}$ is what was reported by Brown $e t$ al. (1995) for 241-SY-103 wastes. A cesium contamination of this level amounts a modest $4.5 \mathrm{ppm}$ contamination of sodium present in the waste. With this assumed contaminated cesium, the overall $\mathrm{Rb} / \mathrm{Cs}$ level is estimated to be $19.4 \%$.

The target counter-ion for the exchange $\left({ }^{137} \mathrm{Cs}\right)$ is thus estimated to represent approximately $19.1 \%$ of the total cesium and rubidium present in the waste. 
WHC-SD-RE-TP-022, Rev. 0

\subsubsection{Exchange Columns}

The test apparatus will operate as two subassemblies for the test of R-F and CST sorption materials. Each subassembly contains a lead and guard column packed with the same materials.

For ease of construction, disposal, and process observation, the columns will be fabricated of glass.

During the loading phase of the column test, the feed solution will be pumped from the feed tank downward through a test column of cesium sorbent. The effluent will be monitored for cesium breakthrough and will be sampled periodically. After passing through the test column, the effluent will pass through a cesium scavenging column to remove any remaining cesium and then flow into the effluent tank. This loading phase will be performed continuously until cesium breakthrough occurs.

The waste from the elution and all the flushes will be sent to a waste tank for disposal. After both sorbent columns are tested, the apparatus will be washed out with deionized (DI) water, decontaminated, and disposed as waste.

The effluent from both the CST and R-F column tests will be retained and provided to subsequent Tanks Focus Area (TFA) tasks which will require the material for technetium (Tc) removal studies.

Periodic samples will be taken of the test column effluent during the loading phase. Samples will also be taken of the feed and the eluate. Sample analyses will be performed to determine the concentration of analytes to which the cesium ion exchange and vitrification processes are sensitive. These analytes include: cesium-137, total cesium, strontium, sodium, potassium, rubidium, aluminum, phosphate, chromium, and iron as well as the $\mathrm{pH}$ of the sample. Effluent from R-F tests will be analyzed for total organic carbon (TOC)

The performance of the sorbents in the removal of cesium from DSSF, and process considerations of such removal, will be evaluated and reported in the final report.

\subsubsection{Theory and Mechanisms of Ion Exchange}

For the purpose of understanding the basis for test actions, a brief description is provided herein of the bases for cesium separation with the test material.

An ion exchange reaction is a reversible interchange of ions between a solid phase and a solution (Harland 1994). In the conduct and performance analysis of ion exchange, it is customary to determine the distribution coefficient $D_{i}$ (Marinsky and Marcus 1995). 
WHC-SD-RE-TP-022, Rev. 0

$$
D_{i}=\frac{\text { concentration of solute in exchanger }}{\text { concentration of solute in solution }}=\left[\frac{\frac{g \text { solute }}{g d r y \text { exchanger }}}{\frac{g \text { solute }}{\text { volume solution }}}\right]
$$

Eqn. (1)

When considering the separation of different ions, the ratio of distribution coefficients of two different ions $\mathrm{A}^{+}$and $\mathrm{B}^{+}$is the separation factor $\alpha_{\mathrm{AB}}$,

$$
\alpha_{A / B}=\frac{D_{A}}{D_{B}}
$$

In general, if $\alpha_{A / B}$ is $>1$, ions $\mathrm{A}$ are more selectively removed from the solution to the ion exchanger than are ions $\mathrm{B}$. Thus, $\alpha_{\mathrm{A} / \mathrm{B}}$ is also termed the selectivity of the exchange material. Series of studies may yield selectivity series (e.g. $\mathrm{Na}<<\mathrm{K}<\mathrm{Cs}<\mathrm{Rb}$ ). These selectivities will be based upon a number of parameters of the exchange, including whether the exchange is through organic or inorganic media.

\subsection{Inorganic Exchange Media}

In inorganic cationic exchange, if an ion exchanger $\mathrm{M}^{-} \mathrm{A}^{+}$, carrying cations $\mathrm{A}^{+}$as the exchanger ions, contacts an aqueous solution containing $\mathrm{B}^{+}$cations, an ion exchange reaction occurs and may be represented as:

$$
M^{-} A^{+}+\underset{B^{+}}{-}+M^{-} B^{+}+A^{+}
$$

Eqn. (3)

In the cation exchange equilibrium represented in Eqn. (3), $\mathrm{M}^{-}$is the insoluble fixed anionic complement of the ion exchanger $\mathrm{M}^{-} \mathrm{A}^{+}$, called the fixed anion. The cations $\mathrm{A}^{+}$and $\mathrm{B}^{+}$are counter-ions, while other ions in the solution with the same charge as the fixed anion are called co-ions.

In the cesium ion exchange test with crystalline silicotitanate, the media will be charged with a hydrogen ion $\left(\mathrm{H}^{+}\right)$which plays the $\mathrm{A}^{+}$part in Eqn. (3). The $\mathrm{B}^{+}$part in the equation is played by the counter-ions of $\mathrm{Li}^{+}, \mathrm{Na}^{+}, \mathrm{K}^{+}, \mathrm{Rb}^{+}$, and $\mathrm{Cs}^{+}$. The extent to which one of these cations is more greatly exchanged with the substrate fixed anion than another counter-ion is termed the selectivity. Primary determining factors in selectivity in inorganic 
ion exchange include: concentration of the exchanging ions, crystallinity of the materials, and solution media and ionic strength.

With regard to crystallinity, for exchange to take place, the cation in the solution must diffuse through the 'windows' connecting cavities in the crystal lattice. When the window is smaller than the diameter of the hydrated counter-ion, part or all of the water molecules of the hydration shell must be lost to allow the cation to pass a window and approach an exchange site. If cations can only pass these windows with the loss of water molecules, the kinetic effects of the reaction will be dependent upon the hydration energies of the various ions. Further, if the counter-ions have larger crystal ionic radii than the opening of the window, the capture effect seen is that of an ion sieve.

An overall description of this effect is that the charge of the fixed anion is sufficient to draw a counter-ion through a window, stripping it of waters of hydration. Once inside the cavity, the material is slowed in exit by its hydrated radius relative to the window and the energy requirement to shed additional water molecules in order to escape.

At this time, the selectivity of crystalline silicotitanate exchange media for the desired cation exchange $\left(\mathrm{Cs}^{+}\right)$appears to be that of the ion sieve effect (Marinsky and Marcus 1995). This has significant bearing upon the expected performance in these tests, both in selectivity of loading and in radiative dose. As tabulated in Table 2, and in application with the engineered structure of the CST material, it is seen that cesium has the highest of these radii. If it enters a crystal cavity for ion exchange, it may be least likely to escape. However, with the beta decays $\left(\beta^{\circ}\right)$ of ${ }^{134} \mathrm{Cs},{ }^{135} \mathrm{Cs}$, and ${ }^{137} \mathrm{Cs}$, of 658,210 , and $514 \mathrm{keV}$ (Walker $e t$ al. 1989), respectively, the captured radioactive cesium would become a more charged barium species $(+2)$ with a smaller crystal radius.
Table 2: Counter-Ion and Decay Product Crystal Radii

\begin{tabular}{||l|c|c|c||}
\hline \multicolumn{4}{|c|}{ Crystal Radii } \\
\hline Element & Charge & $\begin{array}{c}\text { Atomic } \\
\text { Number }\end{array}$ & $\begin{array}{c}\text { Radius } \\
\text { (nm) }\end{array}$ \\
\hline $\mathrm{Na}$ & +1 & 11 & 0.097 \\
\hline $\mathrm{K}$ & +1 & 19 & 0.133 \\
\hline $\mathrm{Rb}$ & +1 & 37 & 0.147 \\
\hline $\mathrm{Ba}$ & +1 & 56 & 0.153 \\
\hline $\mathrm{Ba}$ & +2 & 56 & 0.134 \\
\hline $\mathrm{Cs}$ & +1 & 55 & 0.167 \\
\hline \hline
\end{tabular}

Source: Weast, 60th CRC Handbook of Chemistry and Physics, 1979, F244.

Based upon the crystal ionic radii it is the opinion of the authors, prior to the conduct of this test, that the barium would be significantly more likely to pass through the crystal lattice window to the bulk solution and pass through the exchange bed. 
Ordinarily this release may not be considered a problem as it is inherently the intent of an ion exchange activity to selectively remove one or more species of similar charge. However, in this case the metastable daughter $(94.6 \%)$ [England et al. 1989] of ${ }^{137} \mathrm{Cs},{ }^{137 \mathrm{~m}} \mathrm{Ba}$, has a half-life of 2.552 minutes and a gamma ray decay at $661.7 \mathrm{keV}$. As cesium is loaded onto the bed, with ${ }^{137} \mathrm{Cs}$ in proportion with total cesium, the ${ }^{137 \mathrm{~m}} \mathrm{Ba}$ will be generated at $94.6 \%$ of the activity of the ${ }^{137} \mathrm{Cs}$. If this barium is then leaving the exchanger, the effluent stream will have a gamma activity equal to its split of the integrated ${ }^{137} \mathrm{Cs}$ activity of the influent (i.e. a loading of $0.01 \mathrm{Ci}^{137} \mathrm{Cs} /$ volume of feed for 100 feed volumes will yield an effluent activity of $0.946 \mathrm{Ci}$ of ${ }^{137 m} \mathrm{Ba} /$ effluent volume less its decay in leaving the exchanger). If one were to be monitoring the cesium breakthrough by the daughter gamma decays, one would expect to immediately have the gamma signal from the barium formed after the exchanger $\left({ }^{137} \mathrm{Cs}\right.$ not captured in the exchanger is the final performance measure for the test) swamped by the barium ingrowth from the captured cesium.

This situation is depicted from an example calculation in Figure 2. The net result is the recognition that process applications would have extremely high radiation fields immediately following the exchanger, and that, experimentally, the breakthrough must either be monitored farther down stream ( $\sim 60$ minutes) or monitored by the cesium beta decay as exemplified in Figure 3. In Figure 2 and Figure 3, the cesium plotted is that not captured from a waste feed diluted by a factor of 2 with a decontamination factor (DF) of 1000; the 'd. mBa-137' is the secular equilibrium metastable barium-137 concentration of the cesium plotted; and, the 'Bed $\mathrm{mBa}-137$ ' is the postulated barium bleed from the cesium captured by the exchange material throughout the duration of the test.

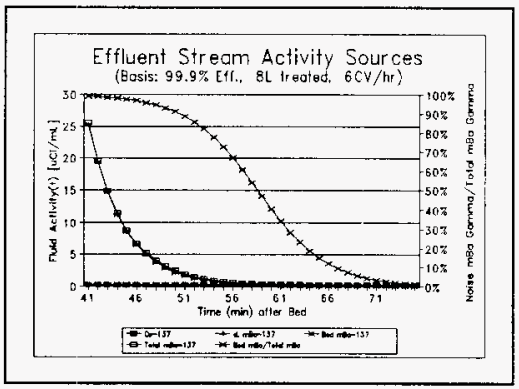

Figure 2: Primary $B / \gamma$ Activity Following the Cesium Extraction

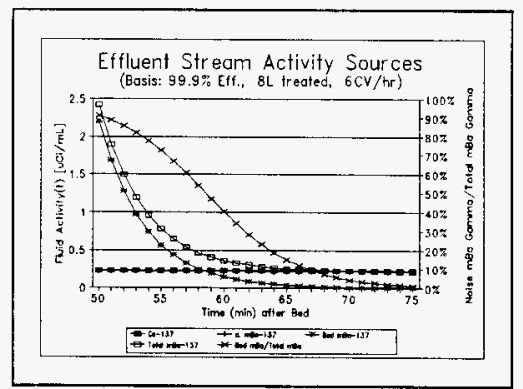

Figure 3: Primary $B / Y$ Signal Separation

Little to no data exist on barium release from crystalline silicotitanate materials, such observation is prudent and will be assessed in this test. 


\subsection{Organic Ion Exchange Media}

The first fully synthetic ion exchange media were organic media made with condensation type polymerization of methanal (formaldehyde) with phenol and polysubstituted benzene compounds to yield, after crushing and grinding, a brittle resin. Among the earliest materials prepared in this way is phenol-formaldehyde; its synthesis is depicted in Figure 4. The functional fixed-ion group in this resin is the sulfonic acid $\left(-\mathrm{SO}_{3} \mathrm{H}\right)$. More recentiy, condensation polymer ion exchange materials have become more varied; the organic exchange material to be tested in this test is that of resorcinol-formaldehyde. The resorcinolformaldehyde resin, with synthesis and cross-linked form depicted in Figure 5, is not functional through a sulfonic acid group but through the hydroxyl $\left(\mathrm{OH}^{-}\right)$group. At elevated

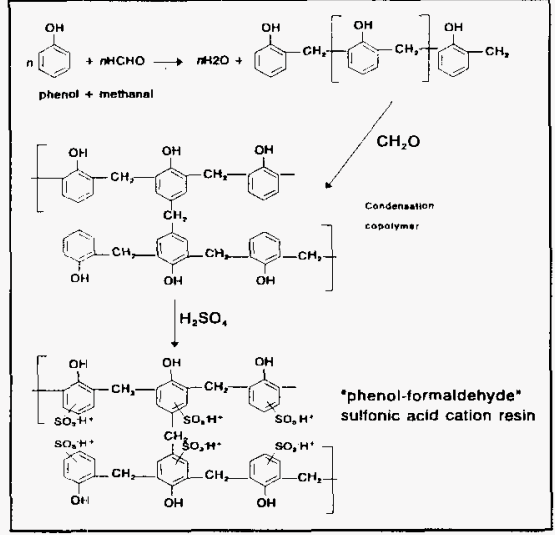

Figure 4: Condensation Polymerization Synthesis of Phenol-Formaldehyde (Harland 1994) $\mathrm{pH}$ levels $(-12)$, the solution is sufficiently basic to strip off the hydrogens (deprotonate) leaving the sites available for ion exchange.

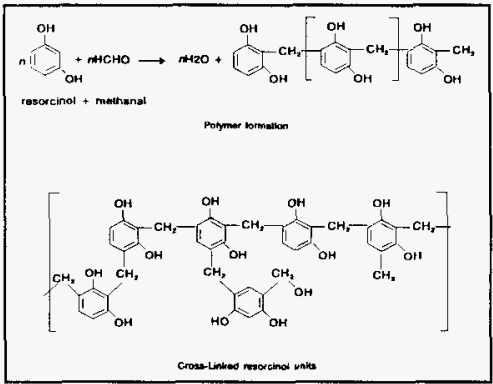

Figure 5: Resorcinol-Formaldehyde Formation and Cross-Linking

It is postulated (Hubler et al. 1995) that the R-F selectivity for cesium that has been demonstrated in prior work, has been primarily associated with the cross-linking and swelling characteristic of the resin. In regions where there is little cross-linking, swelling may be great while little swelling will occur in highly cross-linked regions. The highly cross-linked regions are much more sensitive to the counter-ion size and selectivity (solvation tendency) in these regions. Swelling is thus postulated to occur when a counter-ion is replaced by another counter-ion with a larger hydrated volume and is seen, among alkali metals, to be in sequence $\mathrm{Cs}<\mathrm{Rb}<\mathrm{K}<\mathrm{Na}<\mathrm{Li}$. With the least swelling, the structure should act as if it were more highly cross-linked and thus better able to retain the cesium. 
Hubler et al. (1995) further postulated that the high cross-linking areas of the R-F resin may be the source of observed selectivities for multivalent cations including $\mathrm{Sr}^{2+}, \mathrm{Cr}^{6+}, \mathrm{Fe}^{3+}$, and $\mathrm{Zr}^{4+}$. For the purpose of this test, such selectivities may be beneficial. An observed selectivity for the strontium may lead one to believe that the material may be significantly selective for barium. If such is the case, the integrated ${ }^{137 \mathrm{~m}} \mathrm{Ba}$ wave front discussed as an operational and breakthrough detection difficulty in potential CST operations may not be a consideration in this test. Test instructions are prepared to measure gamma breakthrough far downstream of the R-F column with a contingency of immediate-downstream measurement.

\subsubsection{Resorcinol-Formaldehyde Exchange Column}

The R-F column for the ion exchange test is to be constructed of glass, with a circular cross-section, an internal diameter of $1 \mathrm{~cm}$, and packing height of $10 \mathrm{~cm}$. The R-F exchange material is an organic resin in an engineered form chosen for this test following other investigations of selectivity and loading with simulated and actual Hanford tank wastes (Bray et al. 1990, Kurath et al. 1994, and Brown et al. 1995).

R-F resins have been developed by Dr. Jane Bibler of the Westinghouse Savannah River Company and produced by Boulder Scientific Co. (Mead, CO). The R-F material to be used in this test are to be acquired through the Tanks Focus Area. The final report will include material batch information for the exchange material.

After cesium breakthrough is detected in the R-F test column (Figure 1, C1), the R-F will be flushed with $2 \underline{M}$ sodium hydroxide to remove the feed solution, flushed with de-ionized water to remove the caustic flush solution and to reduce the $\mathrm{pH}$, and then flushed with $0.5 \underline{\mathrm{M}}$ nitric acid to elute the sorbed cesium from the resin. Multiple loads and elutions are not intended in this test. The scavenging column (Figure 1, C2), also to be packed with R-F, is anticipated to be of the same design as the primary R-F column

\subsubsection{Crystalline Silicotitanate Exchange Column}

The CST column for the cesium exchange test is to be constructed of glass, with a circular cross-section, an internal diameter of $1 \mathrm{~cm}$, and packing height of $10 \mathrm{~cm}$. The CST exchange material is an inorganic material designed and fabricated to control crystal lattice spacing such that cesium is selectively captured within the structure. It has been chosen for this test following other investigations of selectivity and loading with simulated wastes (Bray et al. 1993). The CST column (Figure 1, C3) will be packed in an engineered form. The scavenging column (Figure 1, C4), also to be packed with CST, is anticipated to be of the same design as the primary CST column. 
WHC-SD-RE-TP-022, Rev. 0

CSTs have been developed by scientists at Texas A\&M University and the Sandia National Laboratory (SNL) and produced by UOP as IONSIV, IE-911'. The CST material to be used in this test are to be acquired from UOP. The final report will include material batch information for the exchange material.

After cesium breakthrough is detected in the CST test column (Figure 1, C3), the CST will be flushed with $2 \underline{\mathrm{M}}$ sodium hydroxide, eluted (if necessary with $\mathrm{H}_{2} \mathrm{O}$ flush and nitric acid elution) and then drained of all drainable liquid. The CST columns will then be isolated with valves and removed from flow. The bed material will be removed from the columns and digested for disposal. Sample aliquots from the lead column digest will be retained for specific analyses.

\subsection{TEST ENVIRONMENT}

The test environment is primarily that of the WHC operated 222-S analytical laboratories.

During assembly and acceptance testing of the exchange equipment, assembly is largely anticipated to occur in the $306 \mathrm{E}$ laboratories (300 Area) and acceptance testing in nonradioactive portions of the $222-\mathrm{S}$ laboratories. The exchange equipment will be placed into a high-radiation hot cell $(1 \mathrm{~F})$ of the $222-\mathrm{S}$ laboratory where the process tests will occur.

Waste material core samples, retrieved from tank farms will be brought into the 222-S laboratory and extruded in cell 11A. Smaller sample bottles (polyethylene) of the waste supernatant liquor will be transferred from cell $11 \mathrm{~A}$ to cell $\mathrm{lF}$ for the test work.

With the exception of sample analyses at the 222-S laboratory or the Battelle Pacific Northwest National Laboratory 325 laboratory, the remainder of work will be done within the $1 \mathrm{~F}$ hot cell at $222-\mathrm{S}$.

\subsection{EQUIPMENT AND FACILITIES}

Equipment needed for the apparatus assembly and test conduct is detailed in the test procedures (Hendrickson and Duncan 1996). Such equipment includes: exchange columns with bed height adjustment, tubing, valves, a peristaltic pump, exchange materials (R-F resin and CST), a beta-gamma detector probe and data collection system, sample vials, and feed and collection containers.

\footnotetext{
' IONSIV and IE-911 are trademarks of the UOP Co., DesPlains, IL.
} 
Reagents required include deionized water, aqueous solutions of sodium hydroxide, nitric acid, and hydrofluoric acid, and tank waste from tank 241-AW-101. Tank waste volume needs are 4.5 Liters.

Facilities required are those of the $222-\mathrm{S}$ laboratory $1 \mathrm{~F}$ hot cell, and nonradioactive portions of 222-S (building 222-SA) and 306E for equipment assembly and acceptance testing.

\subsection{DATA}

Parameters to be measured, and the precision required is, in large part, defined by the test subtask. In general, the parameters of measurement, when not in chemical assay, are those of interval, volume, mass, and beta/gamma decay measurement. The subtasks to be described herein, and executed in the test procedures and instructions (Hendrickson and Duncan 1996), are waste feed preparation, exchange column packing, conditioning, flush, operation, sampling, elution and waste material handling. Chemical assay quality assurance is described in $\S 8.0$. Data acquisition and handling particular to this test will be defined within the Quality Assurance Project Plan (QAPjP) written to support this test.

\subsection{CRITERIA/CONSTRAINTS}

The nature of this test is that of a treatability test. As such, the activities encompassed within this test are governed by WAC 173-303-071(3)(r) [Treatability Study Samples] and WAC 173-303-071(3)(s) [Samples undergoing treatability studies at laboratories and testing facilities] thereby generating a requirement that the Washington State Department of Ecology (WDOE) be notified, in writing, of the intent to conduct treatability studies no less than 45 days prior to conducting the studies. Treatment of actual waste in the test apparatus shall not proceed unless such a notice compliant with WAC 173-303-071(s)(i) is submitted (WDOE 1994). Compliance with this constraint has been met with treatability test notification for ion exchange (Izatt et al. 1988).

ALARA principles must guide all actions in this test.

\subsection{WASTE MANAGEMENT AND DISPOSAL}

Wastes from the conduct of this test scope will include extraction media, extraction columns, sample bottles, feed bottles (tanks), Tygon ${ }^{2}$ tubing, valves, waste liquor, treatment effluent and elvant, and sampling wastes. All materials having contacted the tank waste liquor must be considered mixed wastes as the tank wastes have been designated to contain F-listed solvents (EPA 1986). To the greatest extent possible, bottles containing wastes brought into

2 Tygon is a trademark of Norton Performance Plastics, Akron, $\mathrm{OH}$. 
WHC-SD-RE-TP-022, Rev. 0

the hot cell will be of polyethylene so that they may be melted down within the cell following use. The extraction media will be dissolved, sampled, and slurped. Eluants, excess and spent samples, and undispositioned effluent will be slurped. Glass vessels will be rinsed, broken (if required), packaged as mixed waste, and removed from the cell for appropriate waste disposal.

Although there has been some consideration for further application of the extraction media, preliminary dose models (Appendix $A$, as described in $\S 7$ ) indicate that shielding sufficient to reduce dose to the 222-S laboratory administrative requirement of $10 \mathrm{mR} / \mathrm{hr}$ would exceed the $18 \mathrm{~kg}(40 \mathrm{lb})$ capacity of the cell manipulators. As such, it cannot be considered safe to remove these materials from the hot cell intact. Preliminary calculations would indicate that achievable removals within the manipulator capacity would not significantly exceed one percent of the loaded CST column $(\sim 60 \mathrm{mg})$ with each loadout. These minute removal capabilities are not considered economically or technically justifiable.

\subsection{EXPECTED RESULTS}

This test will demonstrate the cesium selectivity and load capacity of CST and R-F using actual Hanford DSSF waste. This information will be compared to similar data gathered using simulants and will be used to validate the simulant data's use in the designing of a cesium removal pretreatment process.

Success of these tests will be in the form of chemical analysis and automatic beta/gamma sample counts demonstrating rise in concentration of the effluent cesium beyond $50 \%$ of inlet concentration (breakthrough, $\lambda_{50}$ ) such that the number of column volumes processed at breakthrough be determinable on a constant slope.

Prior development of these sorption materials has indicated that treatment expectations for the R-F resin may vary from 30 to 65 column volumes of waste feed to $\lambda_{50}$ while the CST treatment may vary from 300 to 800 column volumes of waste feed to $\lambda_{50}$. Due to the wide range of these expectations, on-line beta-gamma detection capability will be required to ensure adequate sampling to describe the effluent profile.

\subsection{TEST PROCEDURE}

The content of the test procedure is fully developed within Test Procedures and Instructions for Hanford Tank Waste Supernatant Cesium Removal, WHC-SD-RE-TPI-001 (Hendrickson and Duncan, 1996) and is summarized here. 
The test procedure is partitioned into four primary subdivisions: system acceptance testing and calibration; Resorcinol-Formaldehyde test run preparation, load and elution; crystalline silicotitanate test run preparation, load and elution; system flush, decontamination, and waste management. Sampling procedures are a component of each of these subdivisions of the test and are provided as a fifth component of the test.

Laboratory instruction, as necessary will be developed to implement these laboratory 222-S procedures.

Initial pump calibration and subassembly resin conditioning will be conducted in nonradiologically contaminated conditions. Thus portions of test conduct through conditioning will be conducted serially prior to hot cell entry of the assembly. Subsequent work will be conducted in the sequence specified by the procedure document.

System acceptance testing and calibration procedures include, reagent acquisition, exchange material dissolution, beta-gamma probe calibration, equipment assembly, and flow and leak testing. Reagents to be used in the test work will be acquired from laboratory stores, their specifications are provided in the procedures. Exchange material, for reasons of dose consequence must be dissolved for appropriate disposal, the procedures detail qualitative dissolution procedures to be applied to resin samples prior to hot cell entry. Calibration procedures for the on-line Beta-Gamma probe are defined to ensure appropriate physical sampling by determining when greater than about $10 \%$ breakthrough is occurring. Proceclures are similarly established for nonradiological assembly, flow tests and leak tests.

The R.F test preparation and run is supported with procedures for pump flow rate measurement, exchange column conditioning with nitric acid, dejonized water and sodium hydroxide, waste feed preparation, system flush with sodium hydroxide, test run to an expectation of 80 column volumes $(\sim 630 \mathrm{~mL})$ at 4 column volumes per hour while sampling each fifth column volume of primary column effluent ( $1 \frac{1 / 4}{4}$ hours) and composite effluent sampling. Waste feed procedures detail batch preparation of waste feed by $100 \%$ dilution with deionized water, mixing, settling, centrifugation and sample acquisition. Further procedures detail system flush with sodium hydroxide, primary column elution by water flush and nitric acid elution and composite sampling, and guard column elution by water flush and nitric acid elution.

The CST test preparation and run is supported with procedures for pump flow rate measurement, exchange column conditioning with sodium hydroxide, waste feed preparation, system flush with sodium hydroxide, test run to an expectation of 1,000 column volumes $(\sim 7.85 \mathrm{~L})$ at 6 column volumes per hour while sampling the primary column effluent on a variable frequency (planned: sample/100CV through $500 \mathrm{CV}$ followed by sample $/ 25 \mathrm{CV}$ ) and composite effluent sampling. Waste feed procedures detail batch preparation of waste feed by $100 \%$ dilution with deionized water, mixing, settling, and sample acquisition. Further 
procedures detail system flush with sodium hydroxide. Elution is not planned but may be necessary for the removal of TRU components to facilitate appropriate waste disposal.

System cleanout and waste management procedures detail handling of thermolabile wastes, handling of exchange columns and digestion of resins, disposition of liquors (tank waste, waste feed, rinses, flushes, eluates, effluents, and unspent samples), and disposal of other solid wastes. It is intended that the test effluents will be reserved and shipped by PNNL to their laboratory facilities for further EM-50 work in the development and deployment of technetium ion exchange materials.

Sample analyses detailed include chemical and radiochemical analyses of waste feed batches, primary column effluent and composite (post guard column) effluent samples, eluates, and dissolved resins. Analytical methods, dependent upon need, matrix and funding, are planned to include thermal ionization mass spectroscopy (TIMS), inductively coupled plasma-atomic emission spectroscopy (ICP-AES), gamma energy analysis (GEA), total alpha analysis, beta scintillation (Tc), $\mathrm{OH}^{-}$specific ion electrode (SIE) analysis, suspended solids, and TOC.

\subsection{SAFETY}

Because the waste material to be used in this test is anticipated to yield significant radiation doses if mishandled, the material will be remotely handled, shipped in shielded containers, and tested in hot cell environments. Initial estimates of dose and shielding requirements are contained in Table 3. Details of these dose analyses, for the surface of the appropriately shielded materials, are provided in Appendix A.

As is evidenced, from the Table 3 masses of shielding required to safely remove the materials from the hot cell (shielded to $<10 \mathrm{mR} / \mathrm{hr}$ at contact) the only materials within the $18 \mathrm{~kg}$ capacity of the manipulators are the diluted and treated effluent sample bottles.

From dose perspectives, the remainder of materials must be slurped, or digested and slurped. The digestion of the exchange materials must be demonstrated on non-radioactive materials prior to test start, with safety observations from the digestion included within an appropriate Job Hazard Analysis.

Material Safety Data Sheets regarding appropriate handling and response for reagents used in the test conduct are provided in Appendix B to the test procedure (Hendrickson and Duncan 1996). 
Table 3: Preliminary Dose and Shielding Estimates

\begin{tabular}{|c|c|c|c|c|c|c|c|}
\hline \multicolumn{3}{|c|}{ Source } & \multicolumn{3}{|c|}{ Shield } & \multicolumn{2}{|c|}{ Shielded Source } \\
\hline Description & $\begin{array}{l}\text { Detector } \\
\text { Position }\end{array}$ & $\begin{array}{c}\text { Surface Dose } \\
(\mathrm{mR} / \mathrm{hr})\end{array}$ & Configuration & $\begin{array}{l}\text { Thickness } \\
\text { (cm) }\end{array}$ & $\begin{array}{c}\text { Mass } \\
(\mathbf{k g})\end{array}$ & $\begin{array}{c}\text { Surface Dose } \\
\text { (mR/hr) }\end{array}$ & $\begin{array}{c}\text { Dose at } 30.48 \mathrm{~cm} \\
(\mathrm{mR} / \mathrm{hr})\end{array}$ \\
\hline \multirow[t]{2}{*}{$\begin{array}{l}100 \mathrm{~mL} \text { DSSF } \\
\text { Sample }\end{array}$} & $\begin{array}{l}\text { Side, } \\
\text { Middle }\end{array}$ & $2.506 \mathrm{E}+04$ & Cylindrical & $5.0 \mathrm{~Pb}$ & \multirow[t]{2}{*}{30.2} & 7.32 & 0.347 \\
\hline & End & $\mathbf{n}^{\prime} \mathbf{a}$ & Slab & 4.5 $\mathrm{Pb}$ & & 6.95 & 0.582 \\
\hline \multirow{2}{*}{$\begin{array}{l}\text { Loaded CST } \\
\text { Lead Exchange } \\
\text { Column }\end{array}$} & $\begin{array}{l}\text { Side, } \\
\text { Middle }\end{array}$ & $2.615 \mathrm{E}+06$ & Cylindrical & $7.8 \mathrm{~Pb}$ & \multirow[t]{2}{*}{66.4} & 8.60 & 0.955 \\
\hline & End & $\mathbf{n} / \mathbf{a}$ & Slab & $7.8 \mathrm{~Pb}$ & & 6.84 & 0.509 \\
\hline \multirow{2}{*}{$\begin{array}{l}\text { Loaded CST } \\
\text { Guard Exchange } \\
\text { Column }\end{array}$} & $\begin{array}{l}\text { Side, } \\
\text { Middle }\end{array}$ & $9.807 \mathrm{E}+05$ & Cylindrical & $7.0 \mathrm{~Pb}$ & \multirow[t]{2}{*}{51.0} & 9.43 & 0.895 \\
\hline & End & n/a & Slab & $7.0 \mathrm{~Pb}$ & & 7.49 & 0.489 \\
\hline \multirow[t]{2}{*}{$\begin{array}{l}\text { Eluted R-F Lesd } \\
\text { Exchange Column }\end{array}$} & $\begin{array}{l}\text { Side, } \\
\text { Middle }\end{array}$ & $5.230 \mathrm{E}+1 \mathbf{1 4}$ & Cylindrical & $4.9 \mathrm{~Pb}$ & \multirow[t]{2}{*}{22.2} & 8.97 & 0.390 \\
\hline & End & $\mathrm{n} / \mathrm{a}$ & Slab & $4.9 \mathrm{~Pb}$ & & 7.26 & 0.316 \\
\hline $\begin{array}{l}100 \mathrm{ml} \text { Effluent } \\
\text { DSSF at } 10 \% \mathrm{Cs} \\
\mathrm{DF}\end{array}$ & $\begin{array}{l}\text { Side, } \\
\text { Middle }\end{array}$ & $1.921 \mathrm{E}+01$ & Cylindrical & $0.50 \mathrm{~Pb}$ & 0.86 & 5.97 & 0.054 \\
\hline
\end{tabular}

Doses Calculated with Microshield 3.12, a product of Grove Engineering, Inc., Rockville, MD.

Source Descriptions: DSSF Samples [=] $100 \mathrm{~mL}$ of 241-AW-101 decayed to 6/1/96; CST Lead Column [=] $100 \%$ efficiency estimate for treatment of 4L of DSSF; CST Guard Column $[=] 100 \%$ efficiency estimate for treatment of $1.5 \mathrm{~L}$ of DSSF; R-F Lead Column $I=] 100 \%$ efficiency estimate for treatment of $0.4 \mathrm{~L}$ of DSSF eluted of $80 \%$ of material; Effluent [ =] $100 \mathrm{~mL}$ of $50 \%$ diluted DSSF treated with $1000 \mathrm{DF}$ for Cesium.

\subsection{QUALITY ASSURANCE}

Quality assurance requirements are guided by 10 CFR 830.120 Quality Assurance Requirements (DOE 1994a) and by the Implementation Guide for Use with 10 CFR 830.120 (DOE 1994b). The implementation of 10 CFR 830.120 is through the Quality Assurance Manual (WHC 1996) and facility specific quality assurance plans.

Existent quality assurance requirements encompassed by the Quality Assurance Plan (Meznarich 1995) of the laboratory facilities will be met in the conduct of this work and its chemical analysis. The quality assurance for the conduct of the unit operation and hot cell activities will be in accordance with the approved process testing quality assurance plan (Meznarich 1996). 
WHC-SD-RE-TP-022, Rev. 0

Further details of quality assurance, as required, shall be contained within the test procedures (Hendrickson and Duncan 1996).

\subsection{ORGANIZATION AND FUNCTION RESPONSIBILITIES}

Lead staff on this task are with Westinghouse Hanford Company's (WHC) Process Engineering organization (PE) managed by James A. Hunter. PE staff anticipated to be involved with this task include the Principle Investigator, Douglas W. Hendrickson and Dr. James B. Duncan.

Douglas W. Hendrickson is a Senior Chemical Engineer. Mr. Hendrickson has been active in the sampling, characterization, and pretreatment and treatment of Hanford tank wastes. Recent duties have included those of Principal Investigator for Plasma Calcination of Hanford Waste (EM-30 and EM-50 funded), Principal Investigator for Supercritical Carbon Dioxide Extraction of Solid Mixed Wastes (EM-50 funded), pretreatment application reviews, and Project Engineer for Plasma Arc Vitrification of Hanford Low Level Waste.

Mr. Hendrickson planned and analyzed the last major sampling and characterization of wastes subject to tests proposed in this task (Hendrickson 1992, Welsh 1992).

Dr. James B. Duncan is a Principal Engineer. Dr. Duncan has been active in the area of waste treatment to include radiolysis of recalcitrant organics, water filtration and treatment, and cognizant engineer for the treatability tests for the 100-HR-3 groundwater remediation. Currently he is active in a program for the membrane mediated separation of tritiated water from water and is a coinventor of the process used in that effort.

Scientists and chemical technicians with the WHC 222-S Laboratory Analytical Services organization facilities will be involved in establishing test procedures, operating the test equipment and running the test. Scientific staff anticipated to participate in this task includes Dr. Daniel L. Herting (Senior Principal Scientist) and Mr. Mark A. Beck. Dr. Herting has extensive experience with Hanford Site wastes and process support and is currently the Principal Investigator on EM-50 work entitled 'Selective Crystallization of Tank Supernatant.' Mr. Beck is a radiochemical scientist with extensive experience in handling Hanford Site wastes and detection equipment development (Beck et al. 1996).

Pacific Northwest National Laboratories (PNNL) has performed a great deal of work on cesium removal and will contribute to this effort. They will assist in the test plan preparation and the analysis of the results to ensure that this cesium removal test is performed and results presented in a manner that allow comparison with previous simulant work. PNNL scientists involved with this support will include Garrett N. Brown and Dean E. Kurath. 


\subsection{SCHEDULE}

A detailed schedule of activities is depicted in Figure 6 and milestone activities are listed in Table 4. Manpower loadings and detailed planning costs were provided in a Technical Task Plan provided to EM-50 prior to work initiation. At final reporting, a detail of manpower and costs will be accumulated.

Table 4: Milestone Summary

\begin{tabular}{|c|l|c|c|}
\hline Task & \multicolumn{1}{|c|}{ Work Element / Milestone } & Level & Date \\
\hline A1 & Technical Task Plan Submission & OO & $2 / 05 / 96$ \\
\hline A2 & Performance Management and Reporting & None & \\
\hline A3 & $\begin{array}{l}\text { Draft Test Report Issued } \\
\text { FY 1996 Final Test Report Issued }\end{array}$ & $\begin{array}{c}\text { OO } \\
\text { OO }\end{array}$ & $\begin{array}{c}8 / 16 / 96 \\
9 / 30 / 96\end{array}$ \\
\hline B1 & Test Plan Issued & OO & $6 / 03 / 96$ \\
\hline B2 & Equipment Acquisition & None & \\
\hline B3 & Test Procedure Prepared & WHC & $5 / 06 / 96$ \\
\hline B4 & Test Apparatus installed in Hot Cell & WHC & $5 / 27 / 96$ \\
\hline B5 & DSSF Supernatant Acquired & WHC & $5 / 27 / 96$ \\
\hline C1 & Test Started & WHC & $6 / 03 / 96$ \\
\hline C2 & Testing Complete & OO & $7 / 15 / 96$ \\
\hline C3 & Waste Loadout and Equipment & WHC & $9 / 30 / 96$ \\
\hline
\end{tabular}


'suonteztuegido

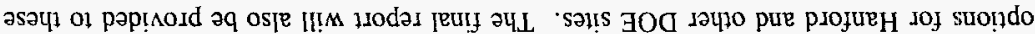

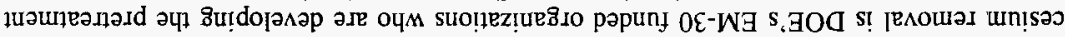

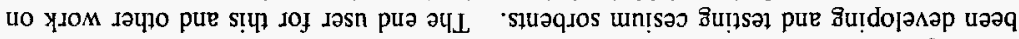

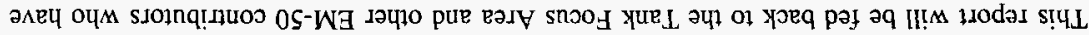

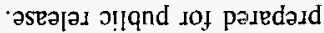

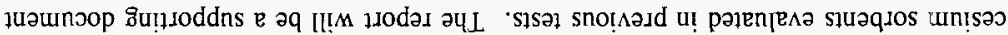

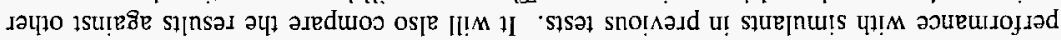

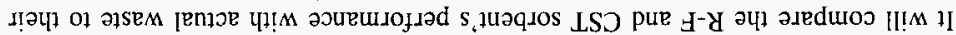

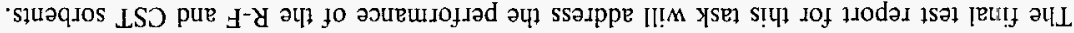

\section{SLYOdGУ $0^{*}$ II}

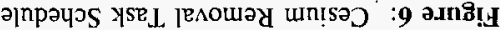

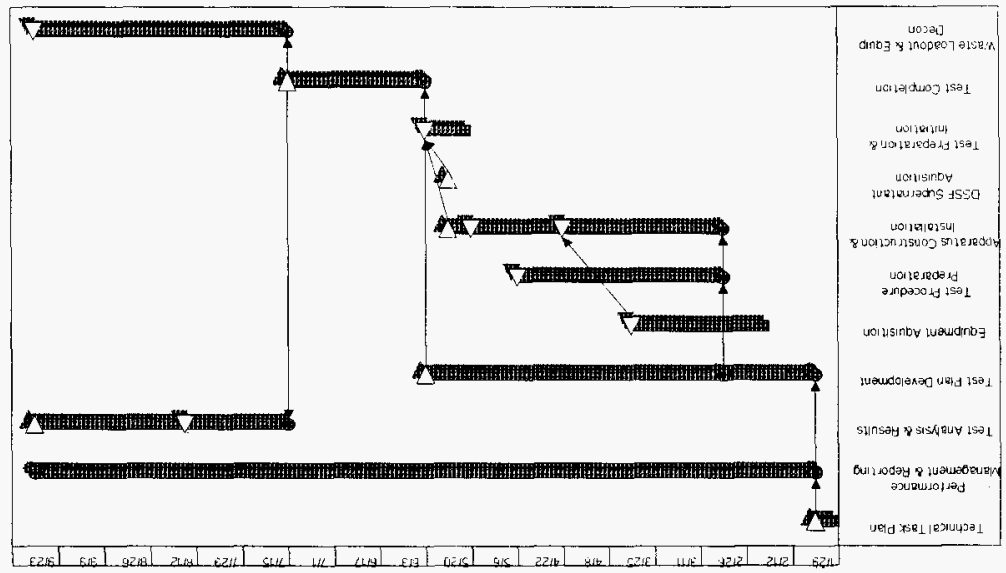

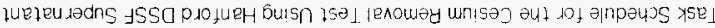




\subsection{DATA SHEETS}

System assembly, waste feed preparation, system operation, and sample collection will be recorded on checksheets and data sheets in the form provided in the test procedures (Hendrickson and Duncan 1996). These data will be recorded into appropriate test logs. Digitally recorded data will be captured, stored on electronic media, printed to a hard copy for retention in the test log, and appended to the final report. Sample analyses returned from chemical or radiochemical assay, will be stored in the laboratory information management system (LIMS) and appended to the final report.

\subsection{REFERENCES}

Barney, G. S., 1976, Vapor-Liquid-Solid Phase Equilibria of Radioactive Sodium Salt Wastes at Hanford, ARH-ST-133, Atlantic Richfield Hanford Company, Richland, Washington, January 1976.

Beck, M. A., R. S. Addleman, G. R. Blewett, E. R. Selle, C. S. McClellan, D. A. Dodd, G. L. Troyer, and B. D. Keele, 1996, Remote Nuclear Screening System for Hostile Environments, WHC-SD-WM-DTR-039, Rev. 0, Westinghouse Hanford Company, Richland, Washington, February 27, 1996.

Benar, C. J., 1996, Tank 241-AW-101 Push Mode Core Sampling and Analysis Plan, WHC-SD-WM-TSAP-024, Rev. 0, Westinghouse Hanford Company, Richland, Washington, January 15, 1996.

Bray, L. A., L. K. Holton, T. R. Meyers, G. M. Richardson, and B. M. Wise, 1984, Experimental Data Developed to Support the Selection of A Treatment Process For West Valley Alkaline Supernatant, PNL-4969, Pacific Northwest Laboratory, Richland, Washington, January 1984.

Bray, L. A., R. J. Elovich, and K. J. Carson, 1990, Cesium Recovery Using Savannah River Laboratory Resorcinol-Formaldehyde Ion Exchange Resin, PNL-7273, Battelle Pacific Northwest Laboratory, March 1990.

Bray, L. A., K. J. Carson, and R. J. Elovich, 1993, Initial Evaluation of Sandia National Laboratory-Prepared Crystalline Silico-Titanates for Cesium Recovery, PNL-8847, Battelle Pacific Northwest Laboratory, October 1993.

Brown, G. N., J. R. Bontha, C. D. Carlson, K. J. Carson, J. R. DesChane, R. J. Elovich, D. E. Kurath, P. K. Tanaka, D. W. Edmonson, D. L. Herting, and J. R. Smith, 1995, Ion Exchange Removal of Cesium from Simulated and Actual Supernate from 
WHC-SD-RE-TP-022, Rev. 0

Hanford Tanks 241-SY-101 and 241-SY-103, PNL-10792, Battelle Pacific Northwest Laboratory, Richland, Washington, September 1995.

Brown, G. N., L. A. Bray, R. J. Elovich, R. L. Bruening, R. M. Decker, T. M. Kafka, and L. R. White, 1995, Evaluation and Comparison of SuperLig 644,

Resorcinol-Formaldehyde and CS-100 Ion Exchange Materials for the Removal of Cesium from Simulated Alkaline Supernate, PNL-10486, Battelle Pacific Northwest Laboratory, Richland, Washington, March 1995.,

Brown, G. N., L. A. Bray, C. D. Carlson, K. J. Carson, J. R. DesChane, R. J. Elovich, F. V. Hoopes, D. E. Kurath, L. L. Nenninger, P. K. Tanaka, 1996, Comparison of Organic and Inorganic Ion Exchangers for Removal of Cesium and Strontium from Simulated and Actual Hanford 24I-AW-101 DSSF Tank Waste, PNL-10920, Battelle Pacific Northwest Laboratory, Richland, Washington, January 1996.

DOE, 1994a, Nuclear Safety Management, "Quality Assurance Requirements,"

10 CFR 830.120, U. S. Department of Energy, Washington D.C., April 5, 1994.

DOE, 1994b, Implementation Guide for Use with 10 CFR 830.120 Quality Assurance, G-830.120-Rev. 0, U. S. Department of Energy, Washington D.C., April 15, 1994.

DOE, 1996, REQUEST FOR PROPOSALS (RFP) NO. DE-RPO6-96RL13308 [TWRS Privatization], Richland, Washington, February 20, 1996.

EPA, 1986, 40 CFR $\$ 261.31$, Hazardous wastes from non-specific sources, U. S. Environmental Protection Agency, Washington, D.C., August 25, 1986.

Eager, K. M., D. L. Penwell, and B. J. Knutson, 1994, Preliminary Flowsheet: Ion Exchange Process for the Separation of Cesium From Hanford Tank Waste Using Duolite CS-100 Resin, WHC-SD-WM-TI-667, Rev. 0, Westinghouse Hanford Company, Richland, Washington.

England, T. R., F. M. Mann, C. W. Reich, and R. E. Schenter, 1989, "ENDF/B-VI Decay and Yield Libraries," Transactions of American Nuclear Society, Vol. 60, 614 (1989).

Harland, C. E., 1994, Ion Exchange: Theory and Practice, 2nd Edition, Royal Society of Chemistry Paperbacks, Cambridge, UK.

${ }^{3}$ SuperLig 644 is a trademark of IBC Advanced Technologies, Provo, UT.

${ }^{4}$ CS-100 is a trademark of the Rohm \& Haas Co., Philadelphia, PA. 
Hedengren, D. C., 1985, ORIGEN2 Predictions of N Reactor Fuel Fission Product Composition, SD-CP-TI-077, Rev. 0, Rockwell Hanford Operations, Richland, Washington, March 4, 1985.

Hendrickson, D. W., 1990, Methods and Data for Use in Determining Source Terms for the Grout Disposal Program, WHC-SD-WM-TI-355, Rev. 0, Westinghouse Hanford Company, Richland, Washington, March 22, 1990.

Hendrickson, D. W., 1992, 241-AW-101 Characterization and Grout Formulation Hot Cell Test Plan, WHC-SD-WM-TP-062, Rev. 1, Westinghouse Hanford Company, Richland, Washington, January 22, 1992.

Hendrickson, D. W., and J. M. Conner, 1994, Grout Treatment Facility Waste Feed Projections, WHC-SD-WM-TI-528, Rev. 1, Westinghouse Hanford Company, Richland, Washington, March 8, 1994.

Hendrickson, D. W., and J. B. Duncan, 1996, Test Procedures and Instructions for Hanford Tank Waste Supernatant Cesium Removal, WHC-SD-RE-TPI-001, Rev. 0, Westinghouse Hanford Company, Richland, Washington, May 31, 1996.

Hubler, T. L., J. A. Franz, W. J. Shaw, S. A. Bryan, R. T. Hallen, G. N. Brown, L. A. Bray, and J. C. Linehan, 1995, Synthesis, Structural Characterization, and Performance Evaluation of Resorcinol-Formaldehyde (R-F) Ion-Exchange Resin, PNL-10744, Battelle Pacific Northwest Laboratory, Richland, Washington, August 1995.

Izatt, R. D., T. D. Chikalla, and R. E. Lerch, 1988, "Notification of Intent to Perform Treatability Tests Exclusive of Resource Conservation and Recovery Act (RCRA) Subtitle (53 Federal Register 27290-27302), "Letter, U. S. DOE, Richland, Operations Office to Mr. Tom Eaton, State of Washington, Departmetn of Ecology, November 9, 1988.

Kurath, D. E., L. A. Bray, W. A. Ross, and D. K. Ploetz, 1989, Correlation of Laboratory Testing and Actual Operations for the West Valley Supernatant Treatment System, PNL-16871, Pacific Northwest Laboratory, Richland, Washington, April 1989.

Kurath, D. E., L. A. Bray, K. P. Brooks, G. N. Brown, S. A. Bryan, C. D. Carlson, K. J. Carson, J. R. DesChane, R. J. Elovich, and A. Y. Kim, 1994, Experimental Data and Analysis to Support the Design of an Ion-Exchange Process for the Treatment of Hanford Tank Waste Supernatant Liquids, PNL-10187, Battelle Pacific Northwest Laboratory, Richland, Washington, December 1994. 
Marinsky, J. A., and Y. Marcus, 1995, Ion Exchange and Solvent Extraction, Vol. 12, (Chapter 9, Mitsou Abe, "Ion-Exchange Selectivities of Inorganic Ion Exchangers"), Marcel Dekker, Inc., New York, New York.

Meznarich, H. K., 1995, 222-S Laboratory Quality Assurance Plan, WHC-SD-CP-QAPP-016, Rev. 0, Westinghouse Hanford Company, Richland, Washington, July $31,1995$.

Meznarich, H. K., 1996, 222-S Process and Development Laboratory Quality Assurance Plan, WHC-SD-CP-QAPP-018, Rev. 0, Westinghouse Hanford Company, Richland, Washington, June 1996.

NRC, 1989, Title 10 Code of Federal Regulations, Part 61, Licensing Requirements for Land Disposal of Radioactive Waste, Nuclear Regulatory Agency, Washington, D.C., May $25,1989$.

ORNL, 1980, A. G. Croff, ORIGEN 2: A Revised and Updated Version of the Oak Ridge Isotope Generation and Depletion Codes, ORNL-5621, Oak Ridge, Tennessee, July 1980.

Penwell, D. L., K. M. Eager, and B. J. Knutson, 1994, Preliminary Flowsheet: Ion Exchange Process for Separation of Cesium From Hanford Tank Waste Using Resorcinol-Formaldehyde Resin, WHC-SD-WM-TI-638, Rev. 0, Westinghouse Hanford Company, Richland, Washington, December 21, 1994.

Walker, F. William, J. F. Parrington, and F. Feiner, 1989, Nuclides and Isotopes, Fourteenth Edition, General Electric Company, San Jose, California.

WDOE, 1994, Washington Administrative Code, Chapter 173-303, Dangerous Waste Regulations, (WAC 173-303), Washington Department of Ecology, Olympia, Washington, January 8, 1994.

Weast, 1979, CRC, Chemical Rubber Company Handbook of Chemistry and Physics, 60th Edition, CRC Press, Inc., Boca Raton, Florida.

Welsh, T. L., 1991, Tank 241-AW-101 Characterization Results, WHC-SD-WM-TRP-055, Rev. 0, Westinghouse Hanford Company, Richland, Washington, December 19, 1991 .

WHC, 1995, Standard Engineering Practices, Engineering Practice 4.2, "Testing Requirements," WHC-CM-6-1, Westinghouse Hanford Company, Richland, Washington. 
WHC-SD-RE-TP-022, Rev. 0

WHC, 1996, Quality Assurance Manual, WHC-CM-4-2, Westinghouse Hanford Company, Richland, Washington. 
WHC-SD-RE-TP-022, Rev. 0

Appendix A: Sample and Material Dose Analyses

A-i 
WHC-SD-RE-TP-022, Rev. 0

THIS PAGE INTENTIONALLY LEFT BLANK

A-ii 
Microshield 3.12

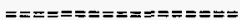

(Westinghouse Hanford Company - \#197)

Page : 1 : DSSFSMP1.MSH

File : DSSFSMP1.MSH
Run date: March 20, 1996

Run time: $1: 33$ p.m.

File Ref: SHLDANL1. OUT

Date: $03 / 20 / 96$

By: DWH

Checked:

CASE: 101AW DSSF $100 \mathrm{~mL}$ Sample Bottle

GEOMETRY 7: Cylindrical source from side - cylindrical shields

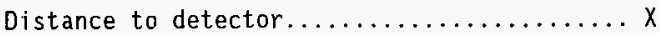

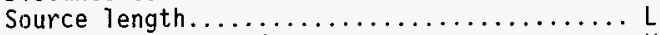

Dose point height from base............. Y

Source cylinder radius................. Tl

Thickness of second shield.............. T2

Microshield inserted air gap.............. air

7.010

8.

4.

2.

5.

0.010

$\mathrm{cm}$.

Source Volume: 100.531 cubic centimeters

MATERIAL DENSITIES $(\mathrm{g} / \mathrm{cc})$ :

\begin{tabular}{|c|c|c|c|}
\hline Material & Source & Shield 2 & Air gap \\
\hline Air & & & .001220 \\
\hline Aluminum & & & \\
\hline Carbon & & & \\
\hline Concrete & & & \\
\hline Hydrogen & & & \\
\hline Iron & & & \\
\hline Lead & & 11.30 & \\
\hline Lithium & & & \\
\hline Nickel & & & \\
\hline Tin & & & \\
\hline Titanium & & & \\
\hline Tungsten & & & \\
\hline Urania & & & \\
\hline Uranium & & & \\
\hline $\begin{array}{l}\text { Water } \\
\text { Zirconium }\end{array}$ & 1.0 & & \\
\hline
\end{tabular}


BUILDUP FACTOR: based on BERGER method. Using the characteristics of 1ead.

\section{INTEGRATION PARAMETERS:}

Number of lateral angle segments (Ntheta).....

Number of azimuthal angle segments (Npsi).... 5

Number of radial segments (Nradius).......... 5

SOURCE NUCLIDES:

\begin{tabular}{llllll} 
Nuclide & \multicolumn{1}{c}{ Curies } & Nuclide & \multicolumn{1}{c}{ Curies } & Nuclide & \multicolumn{1}{c}{ Curies } \\
\hline Am-241 & $1.1900 \mathrm{e}-07$ & $-\mathrm{Ba}-137 \mathrm{~m}$ & $4.2957 \mathrm{e}-02$ & $\mathrm{C}-14$ & $3.7000 \mathrm{e}-08$ \\
$\mathrm{Cm}-243$ & $4.6300 \mathrm{e}-09$ & $\mathrm{C}-60$ & $1.3700 \mathrm{e}-06$ & $\mathrm{Cs}-134$ & $2.1243 \mathrm{e}-05$ \\
$\mathrm{Cs}-135$ & $2.5500 \mathrm{e}-07$ & $\mathrm{Cs}-137$ & $4.5409 \mathrm{e}-02$ & $\mathrm{H}-3$ & $5.0800 \mathrm{e}-07$ \\
$\mathrm{I}-129$ & $3.0300 \mathrm{e}-08$ & $\mathrm{Nb}-94$ & $6.8200 \mathrm{e}-06$ & $\mathrm{~Np}-237$ & $2.1600 \mathrm{e}-07$ \\
Pu-239 & $1.1400 \mathrm{e}-07$ & Ru-106 & $6.8220 \mathrm{e}-05$ & $\mathrm{Se}-79$ & $4.8000 \mathrm{e}-08$ \\
Sr-90 & $9.4300 \mathrm{e}-05$ & Tc-99 & $1.5200 \mathrm{e}-05$ & $\mathrm{Y}-90$ & $9.4300 \mathrm{e}-05$
\end{tabular}

RESULTS :

\begin{tabular}{|c|c|c|c|c|}
\hline$\underset{\#}{\text { Group }}$ & $\begin{array}{l}\text { Energy } \\
(\mathrm{MeV})\end{array}$ & $\begin{array}{c}\text { Activity } \\
\text { (photons/sec) }\end{array}$ & $\begin{array}{l}\text { Dose point flux } \\
\mathrm{MeV} /(\mathrm{sq} \mathrm{cm}) / \mathrm{sec}\end{array}$ & $\begin{array}{c}\text { Dose rate } \\
(m r / h r)\end{array}$ \\
\hline $\begin{array}{r}1 \\
2 \\
3 \\
4 \\
5 \\
6 \\
7 \\
8 \\
9 \\
10 \\
11 \\
12 \\
13 \\
14 \\
15 \\
16 \\
17 \\
18 \\
19 \\
20\end{array}$ & $\begin{array}{r}1.2670 \\
.8724 \\
.6641 \\
.5954 \\
.4766 \\
.2891 \\
.2708 \\
.2035 \\
.1580 \\
.1047\end{array}$ & $\begin{array}{l}1.394 e+05 \\
2.602 e+05 \\
1.431 e+09 \\
9.543 e+05 \\
1.148 e+04 \\
1.248 e+00 \\
3.205 e+02 \\
3.525 e+01 \\
1.374 e+02 \\
1.694 e+02\end{array}$ & $\begin{array}{l}1.281 e+01 \\
4.874 e+00 \\
3.516 e+03 \\
9.797 e-01 \\
5.029 e-04 \\
2.714 e-15 \\
1.464 e-15 \\
2.551 e-26 \\
8.083 e-47 \\
0.000 e+00\end{array}$ & $\begin{array}{l}2.340 \mathrm{e}-02 \\
9.655 \mathrm{e}-03 \\
7.291 \mathrm{e}+00 \\
2.026 \mathrm{e}-03 \\
1.026 \mathrm{e}-06 \\
5.425 \mathrm{e}-18 \\
2.900 \mathrm{e}-18 \\
4.724 \mathrm{e}-29 \\
1.412 \mathrm{e}-49 \\
0.000 \mathrm{e}+00\end{array}$ \\
\hline & OTALS: & $1.433 e+09$ & $3.535 e+03$ & $7.326 \mathrm{e}+00$ \\
\hline
\end{tabular}


Microshield 3.12

$==\boldsymbol{=}=\boldsymbol{=}=\boldsymbol{=}=\mathbf{=}=\mathbf{=}=\mathbf{=}=$

Page : 1 (Westinghouse Hanford Company - \#197)

File : DSSFSMPE.MSH

Run date: March 20, 1996

Run time: 1:34 p.m.

File Ref: SHLDANL1.OUT

Date: $03 / 20 / 96$

By: DWH

Checked:

CASE: 101AW DSSF Sample $100 \mathrm{~mL}$ (End)

GEOMETRY 10: Cylindrical source from end - slab shields

Distance to detector................

Source cyl inder radius.................. R

Source cylinder length................. Tl

Thickness of second shield................. T2

Thickness of third shield.............. T3

13.010

2.

8.

0.010

5.

Cm.
"
"

Source Volume: 100.531 cubic centimeters

MATERIAL DENSITIES $(g / c c)$ :

\begin{tabular}{|c|c|c|c|}
\hline \multirow{2}{*}{\multicolumn{4}{|c|}{ Shield 2}} \\
\hline & & & \\
\hline Aluminum & & & \\
\hline Carbon & & & \\
\hline Concrete & & & \\
\hline Hydrogen & & & \\
\hline Iron & & & \\
\hline Lead & & & 11.30 \\
\hline Lithium & & & \\
\hline Nickel & & & \\
\hline Tin & & & \\
\hline Titanium & & & \\
\hline Tungsten & & & \\
\hline Urania & & & \\
\hline Uranium & & & \\
\hline $\begin{array}{l}\text { Water } \\
\text { Zirconium }\end{array}$ & 1.0 & & \\
\hline
\end{tabular}


CASE: 101AW DSSF Sample $100 \mathrm{~mL}$ (End)

BUILDUP FACTOR: based on BERGER method. Using the characteristics of lead.

\section{INTEGRATION PARAMETERS:}

Number of angle segments (Npsi) ............ 5

Number of radial segments (Nradius) ............ 5

SOURCE NUCLIDES:

\begin{tabular}{llllll} 
Nuclide & \multicolumn{1}{c}{ Curies } & Nuclide & \multicolumn{1}{c}{ Curies } & Nuclide & \multicolumn{1}{c}{ Curies } \\
\hline Am-241 & $1.1900 \mathrm{e}-07$ & Ba-137m & $4.2957 \mathrm{e}-02$ & $\mathrm{C}-14$ & $3.7000 \mathrm{e}-08$ \\
$\mathrm{Cm}-243$ & $4.6300 \mathrm{e}-09$ & $\mathrm{C} 0-60$ & $1.3700 \mathrm{e}-06$ & $\mathrm{Cs}-134$ & $2.1243 \mathrm{e}-05$ \\
$\mathrm{Cs}-135$ & $2.5500 \mathrm{e}-07$ & $\mathrm{Cs}-137$ & $4.5409 \mathrm{e}-02$ & $\mathrm{H}-3$ & $5.0800 \mathrm{e}-07$ \\
$\mathrm{I}-129$ & $3.0300 \mathrm{e}-08$ & Nb-94 & $6.8200 \mathrm{e}-05$ & $\mathrm{~Np}-237$ & $2.1600 \mathrm{e}-07$ \\
Pu-239 & $1.1400 \mathrm{e}-07$ & Ru-106 & $6.8220 \mathrm{e}-05$ & $\mathrm{Se}-79$ & $4.8000 \mathrm{e}-08$ \\
Sr-90 & $9.4300 \mathrm{e}-05$ & Tc -99 & $1.5200 \mathrm{e}-05$ & $\mathrm{Y}-90$ & $9.4300 \mathrm{e}-05$
\end{tabular}

RESULTS:

\begin{tabular}{|c|c|c|c|c|}
\hline$\underset{\#}{\text { Group }}$ & $\begin{array}{l}\text { Energy } \\
(\mathrm{MeV})\end{array}$ & $\begin{array}{c}\text { Activity } \\
\text { (photons/sec) }\end{array}$ & $\begin{array}{l}\text { Dose point flux } \\
\operatorname{MeV} /(\mathrm{sq} \mathrm{cm}) / \mathrm{sec}\end{array}$ & $\begin{array}{c}\text { Dose rate } \\
(\mathrm{mr} / \mathrm{hr})\end{array}$ \\
\hline $\begin{array}{c}1 \\
2 \\
3 \\
4 \\
5 \\
6 \\
7 \\
8 \\
9 \\
10 \\
11 \\
12 \\
13 \\
14 \\
15 \\
16 \\
17 \\
18 \\
19 \\
20\end{array}$ & $\begin{array}{r}1.2670 \\
.8724 \\
.6641 \\
.5954 \\
.4766 \\
.2891 \\
.2708 \\
.2035 \\
.1580 \\
.1047\end{array}$ & $\begin{array}{l}1.394 e+05 \\
2.502 e+05 \\
1.431 e+09 \\
9.543 e+05 \\
1.148 e+04 \\
1.248 e+00 \\
3.205 e+02 \\
3.525 e+01 \\
1.374 e+02 \\
1.694 e+02\end{array}$ & $\begin{array}{l}1.208 \mathrm{e}+01 \\
4.902 \mathrm{e}+00 \\
3.877 \mathrm{e}+03 \\
1.121 \mathrm{e}+00 \\
6.581 \mathrm{e}-04 \\
5.646 \mathrm{e}-15 \\
3.374 \mathrm{e}-15 \\
7.596 \mathrm{e}-26 \\
3.664 \mathrm{e}-46 \\
0.000 \mathrm{e}+00\end{array}$ & $\begin{array}{l}2.206 \mathrm{e}-02 \\
9.712 \mathrm{e}-03 \\
8.040 \mathrm{e}+00 \\
2.319 \mathrm{e}-03 \\
1.343 \mathrm{e}-06 \\
1.129 \mathrm{e}-17 \\
6.684 \mathrm{e}-18 \\
1.407 \mathrm{e}-28 \\
6.399 \mathrm{e}-49 \\
0.000 \mathrm{e}+00\end{array}$ \\
\hline & OTALS: & $1.433 e+09$ & $3.895 \mathrm{e}+03$ & $8.074 \mathrm{e}+00$ \\
\hline
\end{tabular}


Microshield 3.12

$=============-=$

Page : 1 (Westinghouse Hanford Company - \#197)

File : CSTLEAD.MSH

Run date: March 20, 1996

Run time: $1: 34$ p.m.

File Ref: SHLDANL1.OUT

Date: $03 / 20 / 96$

By: DWH

Checked:

CASE: Cesium Ion Exchange Column (CST at 1.82 Ci CS137)

GEOMETRY 7: Cylindrical source from side - cylindrical shields

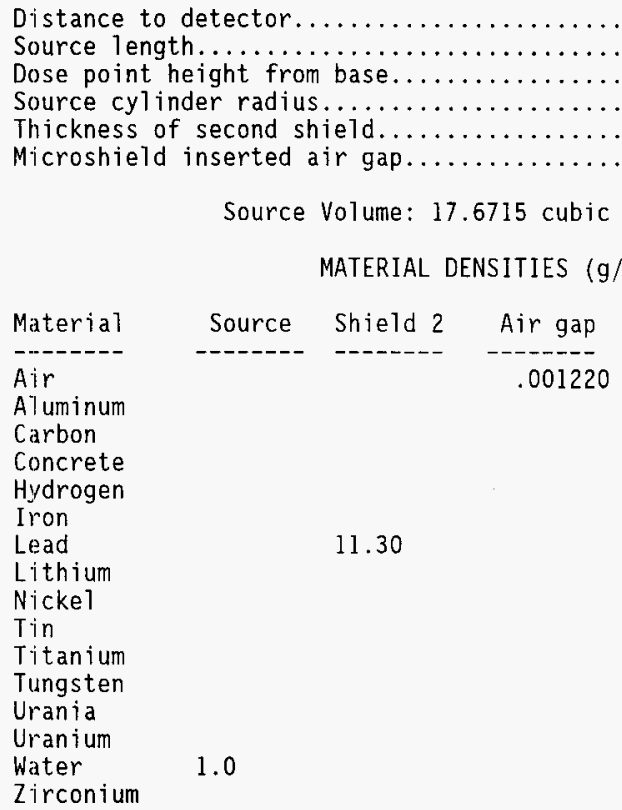

$8.560 \mathrm{~cm}$.

10 .

5.

0.750

7.8

0.010

imeters 
BUILDUP FACTOR: based on BERGER method. Using the characteristics of lead.

\section{INTEGRATION PARAMETERS:}

Number of lateral angle segments (Ntheta)..... 5

Number of azimuthal angle segments (Npsi)..... 5 Number of radial segments (Nradius)...........

SOURCE NUCLIDES:

\begin{tabular}{llllll} 
Nuclide & \multicolumn{1}{c}{ Curies } & Nuclide & \multicolumn{1}{c}{ Curies } & Nuclide & \multicolumn{1}{c}{ Curies } \\
\hdashline Ba-137m & $1.7182 \mathrm{e}+00$ & Co-60 & $5.4800 \mathrm{e}-05$ & Cs-134 & $8.4972 \mathrm{e}-04$ \\
Cs-135 & $1.0200 \mathrm{e}-05$ & Cs-137 & $1.8163 \mathrm{e}+00$ & Np-237 & $8.6400 \mathrm{e}-06$ \\
Pu-239 & $4.5600 \mathrm{e}-06$ & Sr-90 & $3.7720 \mathrm{e}-03$ & $\mathrm{Y}-90$ & $3.7720 \mathrm{e}-03$
\end{tabular}

RESULTS:

\begin{tabular}{|c|c|c|c|c|}
\hline Group & $\begin{array}{l}\text { Energy } \\
(\mathrm{MeV})\end{array}$ & $\begin{array}{c}\text { Activity } \\
\text { (photons/sec) }\end{array}$ & $\begin{array}{l}\text { Dose point flux } \\
\mathrm{MeV} /(\mathrm{sq} \mathrm{cm}) / \mathrm{sec}\end{array}$ & $\begin{array}{c}\text { Dose rate } \\
(\mathrm{mr} / \mathrm{hr})\end{array}$ \\
\hline $\begin{array}{l}1 \\
2 \\
3 \\
4 \\
5 \\
6 \\
7 \\
8 \\
9 \\
10 \\
11 \\
12 \\
13 \\
14 \\
15 \\
16 \\
17 \\
18 \\
19 \\
20\end{array}$ & $\begin{array}{r}1.2670 \\
1.0391 \\
.6641 \\
.6016 \\
.5703 \\
.4766 \\
.2734 \\
.2021 \\
.1580 \\
.1038\end{array}$ & $\begin{array}{l}5.577 e+06 \\
3.144 e+05 \\
5.723 e+10 \\
3.069 e+07 \\
7.486 e+06 \\
4.590 e+05 \\
1.113 e+04 \\
1.184 e+03 \\
5.474 e+03 \\
4.445 e+03\end{array}$ & $\begin{array}{l}6.744 \mathrm{e}+01 \\
1.495 \mathrm{e}+00 \\
4.085 \mathrm{e}+03 \\
7.419 \mathrm{e}-01 \\
6.593 \mathrm{e}-02 \\
8.692 \mathrm{e}-05 \\
5.389 \mathrm{e}-21 \\
6.985 \mathrm{e}-38 \\
1.586 \mathrm{e}-69 \\
0.000 \mathrm{e}+00\end{array}$ & $\begin{array}{l}1.232 \mathrm{e}-01 \\
2.861 \mathrm{e}-03 \\
8.471 \mathrm{e}+00 \\
1.535 \mathrm{e}-03 \\
1.359 \mathrm{e}-04 \\
1.774 \mathrm{e}-07 \\
1.069 \mathrm{e}-23 \\
1.291 \mathrm{e}-40 \\
2.770 \mathrm{e}-72 \\
0.000 \mathrm{e}+00\end{array}$ \\
\hline & OTALS: & $5.728 \mathrm{e}+10$ & & \\
\hline
\end{tabular}


Microshield 3.12

$===============$

(Westinghouse Hanford Company - \#197)

Page : 1

File : CSTLEADE.MSH

Run date: March 20, 1996

Run time: $1: 34$ p.m.

File Ref: SHLDANL1.OUT Date: $03 / 20 / 96$

By: DWH

Checked:

CASE: CST Lead Column from End (CST 1.82Ci)

GEOMETRY 10: Cylindrical source from end - slab shields

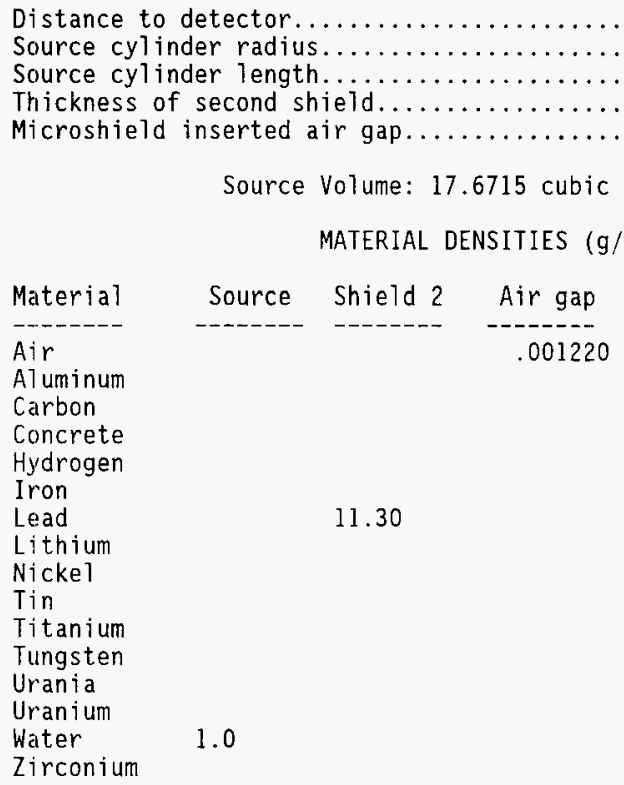

$\begin{array}{lr}17.810 & \mathrm{~cm} . \\ 0.750 & " 1 \\ 10 . & " \\ 7.8 & " \\ 0.010 & "\end{array}$


BUILDUP FACTOR: based on BERGER method. Using the characteristics of lead.

\section{INTEGRATION PARAMETERS:}

Number of angle segments (Npsi)..............

SOURCE NUCLIDES:

\begin{tabular}{llllll} 
Nuclide & \multicolumn{1}{c}{ Curies } & Nuclide & \multicolumn{1}{c}{ Curies } & Nuclide & Curies \\
\hline Ba-137m & $1.7182 \mathrm{e}+00$ & $-00-60$ & $-5.4800 \mathrm{e}-05$ & $\mathrm{Cs}-134$ & $8.4972 \mathrm{e}-04$ \\
Cs-135 & $1.0200 \mathrm{e}-05$ & Cs -137 & $1.8163 \mathrm{e}+00$ & Np-237 & $8.6400 \mathrm{e}-06$ \\
Pu-239 & $4.5600 \mathrm{e}-06$ & Sr-90 & $3.7720 \mathrm{e}-03$ & $\mathrm{Y}-90$ & $3.7720 \mathrm{e}-03$
\end{tabular}

RESULTS:

\begin{tabular}{|c|c|c|c|c|}
\hline$\underset{\#}{\text { Group }}$ & $\begin{array}{l}\text { Energy } \\
(\mathrm{MeV})\end{array}$ & $\begin{array}{c}\text { Activity } \\
\text { (photons/sec) }\end{array}$ & $\begin{array}{l}\text { Dose point flux } \\
\mathrm{MeV} /(\mathrm{sq} \mathrm{cm}) / \mathrm{sec}\end{array}$ & $\begin{array}{c}\text { Dose rate } \\
(\mathrm{mr} / \mathrm{hr})\end{array}$ \\
\hline $\begin{array}{r}1 \\
2 \\
3 \\
4 \\
5 \\
6 \\
7 \\
8 . \\
9 \\
10 \\
11 \\
12 \\
13 \\
14 \\
15 \\
16 \\
17 \\
18 \\
19 \\
20\end{array}$ & $\begin{array}{l}1.2670 \\
1.0391 \\
.6641 \\
.6016 \\
.5703 \\
.4766 \\
.2734 \\
.2021 \\
.1580 \\
.1038\end{array}$ & $\begin{array}{l}5.577 \mathrm{e}+06 \\
3.144 \mathrm{e}+05 \\
5.723 \mathrm{e}+10 \\
3.069 \mathrm{e}+07 \\
7.486 \mathrm{e}+06 \\
4.590 \mathrm{e}+05 \\
1.113 \mathrm{e}+04 \\
1.184 \mathrm{e}+03 \\
5.474 \mathrm{e}+03 \\
4.445 \mathrm{e}+03\end{array}$ & $\begin{array}{l}4.629 \mathrm{e}+01 \\
1.048 \mathrm{e}+00 \\
3.257 \mathrm{e}+03 \\
6.114 \mathrm{e}-01 \\
5.620 \mathrm{e}-02 \\
8.378 \mathrm{e}-05 \\
1.110 \mathrm{e}-20 \\
2.354 \mathrm{e}-37 \\
1.072 \mathrm{e}-68 \\
0.000 \mathrm{e}+00\end{array}$ & $\begin{array}{l}8.456 \mathrm{e}-02 \\
2.005 \mathrm{e}-03 \\
6.754 \mathrm{e}+00 \\
1.265 \mathrm{e}-03 \\
1.159 \mathrm{e}-04 \\
1.709 \mathrm{e}-07 \\
2.201 \mathrm{e}-23 \\
4.351 \mathrm{e}-40 \\
1.872 \mathrm{e}-71 \\
0.000 \mathrm{e}+00\end{array}$ \\
\hline & OTALS: & $5.728 e+10$ & $3.305 e+03$ & $6.842 e+00$ \\
\hline
\end{tabular}


Microshield 3.12

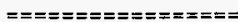

(Westinghouse Hanford Company - \#197)

Page : 1

File : CSTGRD.MSH

Run date: March 20, 1996

Run time: $1: 34$ p.m.

File Ref: SHLDANL1.OUT

Date: $03 / 20 / 96$

By: $\underline{\mathrm{DWH}}$

Checked:

CASE : Cesium Ion Exchange Guard Column (CST at $0.68 \mathrm{Ci}$ CS137)

GEOMETRY 7: Cylindrical source from side - cylindrical shields

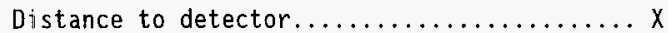

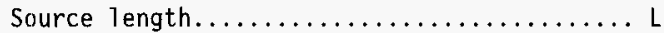

Dose point height from base.............. Y

Source cylinder radius................ Tl

Thickness of second shield............... T2

Microshield inserted air gap............. air

$7.760 \mathrm{~cm}$.

10.

5.

0.750

7 .

0.010

Source Volume: 17.6715 cubic centimeters

MATERIAL DENSITIES $(\mathrm{g} / \mathrm{cc})$ :

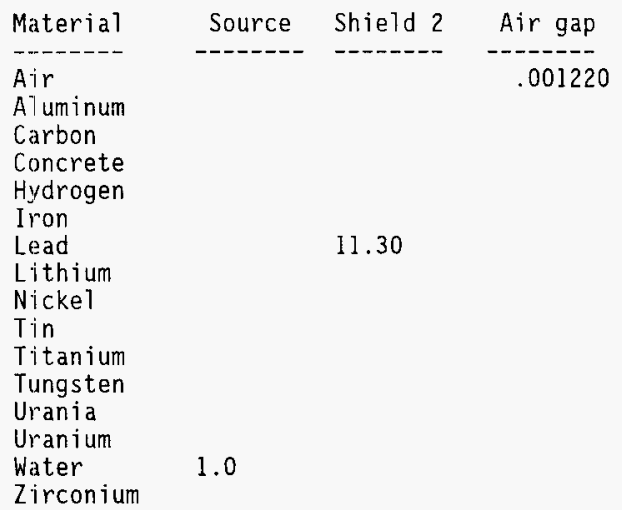


BUILDUP FACTOR: based on BERGER method. Using the characteristics of lead.

\section{INTEGRATION PARAMETERS:}

Number of lateral angle segments (Ntheta)..... Number of azimuthal angle segments (Npsi).....

Number of radial segments (Nradius) ........... 5

5

5

\section{SOURCE NUCLIDES:}

\begin{tabular}{llllll} 
Nuclide & \multicolumn{1}{c}{ Curies } & Nuclide & \multicolumn{1}{c}{ Curies } & Nuclide & \multicolumn{1}{c}{ Curies } \\
\hdashline Ba-137m & $6.4434 \mathrm{e}-01$ & Co-60 & $2.0550 \mathrm{e}-05$ & Cs-134 & $3.1865 \mathrm{e}-04$ \\
$\mathrm{Cs}-135$ & $3.8250 \mathrm{e}-06$ & $\mathrm{Cs}-137$ & $6.8112 \mathrm{e}-01$ & Np-237 & $3.2400 \mathrm{e}-06$ \\
$\mathrm{Pu}-239$ & $1.7100 \mathrm{e}-06$ & Sr-90 & $1.4145 \mathrm{e}-03$ & $\mathrm{Y}-90$ & $1.4145 \mathrm{e}-03$
\end{tabular}

RESULTS:

\begin{tabular}{|c|c|c|c|c|}
\hline$\underset{\#}{G r o u p}$ & $\begin{array}{l}\text { Energy } \\
\text { (MeV) }\end{array}$ & $\begin{array}{c}\text { Activity } \\
\text { (photons/sec) }\end{array}$ & $\begin{array}{l}\text { Dose point flux } \\
\mathrm{MeV} /(\mathrm{sq} \mathrm{cm}) / \mathrm{sec}\end{array}$ & $\begin{array}{c}\text { Dose rate } \\
(\mathrm{mr} / \mathrm{hr})\end{array}$ \\
\hline $\begin{array}{c}1 \\
2 \\
3 \\
4 \\
5 \\
6 \\
7 \\
8 \\
9 \\
10 \\
11 \\
12 \\
13 \\
14 \\
15 \\
16 \\
17 \\
18 \\
19 \\
20\end{array}$ & $\begin{array}{l}-.-1.2670 \\
1.0391 \\
.6641 \\
.6016 \\
.5703 \\
.4766 \\
.2734 \\
.2021 \\
.1580 \\
.1038\end{array}$ & $\begin{array}{l}2.091 \mathrm{e}+06 \\
1.179 \mathrm{e}+05 \\
2.146 \mathrm{e}+10 \\
1.151 \mathrm{e}+07 \\
2.807 \mathrm{e}+06 \\
1.721 \mathrm{e}+05 \\
4.174 \mathrm{e}+03 \\
4.441 \mathrm{e}+02 \\
2.053 \mathrm{e}+03 \\
1.667 \mathrm{e}+03\end{array}$ & $\begin{array}{l}4.811 \mathrm{e}+01 \\
1.145 \mathrm{e}+00 \\
4.507 \mathrm{e}+03 \\
9.004 \mathrm{e}-01 \\
8.788 \mathrm{e}-02 \\
1.660 \mathrm{e}-04 \\
2.749 \mathrm{e}-19 \\
1.367 \mathrm{e}-34 \\
5.665 \mathrm{e}-63 \\
0.000 \mathrm{e}+00\end{array}$ & $\begin{array}{l}8.787 \mathrm{e}-02 \\
2.193 \mathrm{e}-03 \\
9.346 \mathrm{e}+00 \\
1.863 \mathrm{e}-03 \\
1.812 \mathrm{e}-04 \\
3.387 \mathrm{e}-07 \\
5.452 \mathrm{e}-22 \\
2.527 \mathrm{e}-37 \\
9.894 \mathrm{e}-66 \\
0.000 \mathrm{e}+00\end{array}$ \\
\hline & JTALS: & $2.148 \mathrm{e}+10$ & $4.557 \mathrm{e}+03$ & $9.438 \mathrm{e}+00$ \\
\hline
\end{tabular}


Microshield 3.12

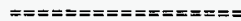

Page : 1 (Westinghouse Hanford Company - \#197)

File : CSTGRDE.MSH

Run date: March 20, 1996

Run time: $1: 34$ p.m.

File Ref: SHLDANLI.OUT

Date: $03 / 20 / 96$

By: DWH

Checked:

CASE: CST Guard Column from End (CST 0.68 Ci CS-137)

GEOMETRY 10: Cylindrical source from end - slab shields

Distance to detector.................... X

Source cylinder radius................... $\mathrm{R}$

Source cylinder length.................. T1

Thickness of second shield............... T2

Microshield inserted air gap.............. air

17.010

0.750

$\mathrm{cm}$.

10.

7.

0.010

II

II

Source Volume: 17.6715 cubic centimeters

MATERIAL DENSITIES $(\mathrm{g} / \mathrm{cc})$ :

\begin{tabular}{lccc} 
Material & Source & Shield 2 & Air gap \\
\hline Air & & & .001220 \\
Aluminum & & & \\
Carbon & & & \\
Concrete & & & \\
Hydrogen & & & \\
Iron & & 11.30 & \\
Lead & & & \\
Lithium & & & \\
Nicke1 & & \\
Tin & & \\
Titanium & & \\
Tungsten & & \\
Urania & & \\
Uranium & & \\
Water & 1.0 & \\
Zirconium & &
\end{tabular}


CASE: CST Guard Column from End (CST $0.68 \mathrm{Ci}$ Cs-137)

BUILDUP FACTOR: based on BERGER method.

Using the characteristics of lead.

\section{INTEGRATION PARAMETERS:}

Number of angle segments (Npsi)........... 5

Number of radial segments (Nradius) .......... 5

\begin{tabular}{|c|c|c|c|c|c|}
\hline \multirow[b]{2}{*}{ Nucl ide } & \multicolumn{3}{|c|}{ SOURCE NUCLIDES: } & \multirow[b]{2}{*}{ Nuclide } & \multirow[b]{2}{*}{ Curies } \\
\hline & Curies & Nuclide & Curies & & \\
\hline------- & $-----\cdots--$ & ------ & --------- & ------- & $--------r$ \\
\hline $\begin{array}{l}\mathrm{Ba}-137 \mathrm{~m} \\
\mathrm{Cs}-135 \\
\mathrm{Pu}-239\end{array}$ & $\begin{array}{l}6.4434 \mathrm{e}-01 \\
3.8250 \mathrm{e}-06 \\
1.7100 \mathrm{e}-06\end{array}$ & $\begin{array}{l}C 0-60 \\
C s-137 \\
S r-90\end{array}$ & $\begin{array}{l}2.0550 e-05 \\
6.8112 e-01 \\
1.4145 e-03\end{array}$ & $\begin{array}{l}\mathrm{Cs}-134 \\
\mathrm{~Np}-237 \\
\mathrm{Y}-90\end{array}$ & $\begin{array}{l}3.1865 \mathrm{e}-04 \\
3.2400 \mathrm{e}-06 \\
1.4145 \mathrm{e}-03\end{array}$ \\
\hline
\end{tabular}

RESULTS:

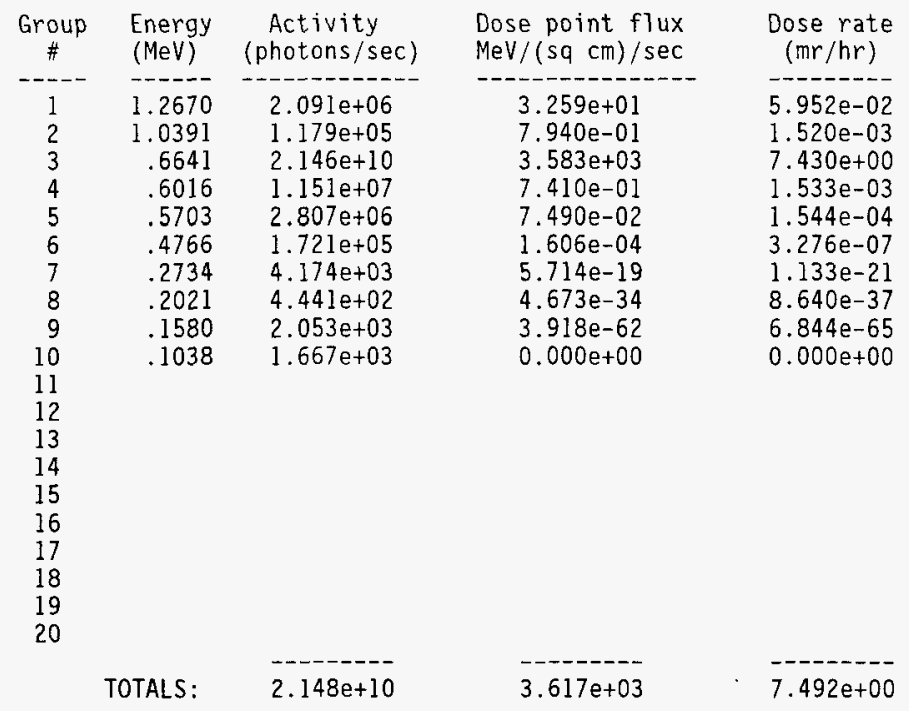


Microshield 3.12

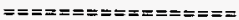

Page : 1 (Westinghouse Hanford Company - \#197)

File : RFLEAD.MSH

Run date: March 20, 1996

Run time: $1: 34$ p.m.

File Ref: SHLDANL1.OUT

Date: $03 / 20 / 96$

By: $\underline{D W H}$

Checked:

CASE: Cesium Ion Exchange Column (Eluted R-F at $0.036 \mathrm{Ci} \mathrm{Cs137)}$

GEOMETRY 7: Cylindrical source from side - cylindrical shields

Distance to detector.................

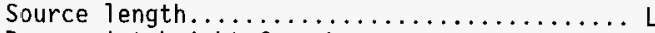

Dose point height from base..............

Source cyl inder radius................. Tl

Thickness of second shield............... T2

Microshield inserted air gap............... air

5.660

10.

5.

0.750

4.9

0.010

$\mathrm{cm}$.

Source Volume: 17.6715 cubic centimeters

MATERIAL DENSITIES $(\mathrm{g} / \mathrm{cc})$ :

\begin{tabular}{|c|c|c|c|}
\hline Material & Source & Shield 2 & Air gap \\
\hline $\begin{array}{l}\text { Air } \\
\text { Aluminum }\end{array}$ & & & .001220 \\
\hline Carbon & & & \\
\hline Concrete & & & \\
\hline Hydrogen & & & \\
\hline Iron & & & \\
\hline Lead & & 11.30 & \\
\hline Lithium & & & \\
\hline Nickel & & & \\
\hline Tin & & & \\
\hline Titanium & & & \\
\hline Tungsten & & & \\
\hline Urania & & & \\
\hline Uranium & & & \\
\hline Water & 1.0 & & \\
\hline Zirconium & & & \\
\hline
\end{tabular}


CASE: Cesium Ion Exchange Column (Eluted R-F at $0.036 \mathrm{Ci}$ Cs137)

BUILDUP FACTOR: based on BERGER method. Using the characteristics of lead.

\section{INTEGRATION PARAMETERS:}

Number of lateral angle segments (Ntheta).... 5

Number of azimuthal angle segments (Npsi).... 5

Number of radial segments (Nradius) ............ 5

SOURCE NUCLIDES:

\begin{tabular}{llllll} 
Nuclide & \multicolumn{1}{c}{ Curies } & Nuclide & \multicolumn{1}{c}{ Curies } & Nuclide & \multicolumn{1}{c}{ Curies } \\
\hline $\mathrm{Ba}-137 \mathrm{~m}$ & $3.4364 \mathrm{e}-02$ & $\mathrm{Co}-60$ & $1.0960 \mathrm{e}-06$ & $\mathrm{Cs}-134$ & $1.6994 \mathrm{e}-05$ \\
$\mathrm{Cs}-135$ & $2.0400 \mathrm{e}-07$ & $\mathrm{Cs}-137$ & $3.6326 \mathrm{e}-02$ & $\mathrm{~Np}-237$ & $1.7280 \mathrm{e}-07$ \\
Pu-239 & $9.1200 \mathrm{e}-08$ & $\mathrm{Sr}-90$ & $7.5440 \mathrm{e}-05$ & $\mathrm{Y}-90$ & $7.5440 \mathrm{e}-05$
\end{tabular}

RESULTS:

\begin{tabular}{|c|c|c|c|c|}
\hline$\underset{\#}{\text { Group }}$ & $\begin{array}{l}\text { Energy } \\
(\mathrm{MeV})\end{array}$ & $\begin{array}{c}\text { Activity } \\
\text { (photons/sec) }\end{array}$ & $\begin{array}{l}\text { Dose point flux } \\
\operatorname{MeV} /(\mathrm{sq} \mathrm{cm}) / \mathrm{sec}\end{array}$ & $\begin{array}{c}\text { Dose rate } \\
(\mathrm{mr} / \mathrm{hr})\end{array}$ \\
\hline $\begin{array}{c}--- \\
1 \\
3 \\
3 \\
4 \\
5 \\
6 \\
7 \\
8 \\
9 \\
10 \\
11 \\
12 \\
13 \\
14 \\
15 \\
16 \\
17 \\
18 \\
19 \\
20\end{array}$ & $\begin{array}{l}-.-1 .- \\
1.2670 \\
.0391 \\
.6641 \\
.6016 \\
.5703 \\
.4765 \\
.2734 \\
.2021 \\
.1580 \\
.1038\end{array}$ & $\begin{array}{l}1.115 \mathrm{e}+05 \\
6.288 \mathrm{e}+03 \\
1.145 \mathrm{e}+09 \\
6.137 \mathrm{e}+05 \\
1.497 \mathrm{e}+05 \\
9.180 \mathrm{e}+03 \\
2.226 \mathrm{e}+02 \\
2.368 \mathrm{e}+01 \\
1.095 \mathrm{e}+02 \\
8.889 \mathrm{e}+01\end{array}$ & $\begin{array}{l}1.471 \mathrm{e}+01 \\
4.222 \mathrm{e}-01 \\
4.313 \mathrm{e}+03 \\
1.107 \mathrm{e}+00 \\
1.381 \mathrm{e}-01 \\
6.708 \mathrm{e}-04 \\
6.791 \mathrm{e}-15 \\
4.600 \mathrm{e}-26 \\
6.989 \mathrm{e}-46 \\
0.000 \mathrm{e}+00\end{array}$ & $\begin{array}{l}-1 .---- \\
2.687 \mathrm{e}-02 \\
8.082 \mathrm{e}-04 \\
8.942 \mathrm{e}+00 \\
2.289 \mathrm{e}-03 \\
2.847 \mathrm{e}-04 \\
1.369 \mathrm{e}-06 \\
1.347 \mathrm{e}-17 \\
8.505 \mathrm{e}-29 \\
1.221 \mathrm{e}-48 \\
0.000 \mathrm{e}+00\end{array}$ \\
\hline & TTALS: & $1.146 \mathrm{e}+09$ & $4.329 e+03$ & $8.973 \mathrm{e}+00$ \\
\hline
\end{tabular}


Microshield 3.12

$==== \pm========x==0$

(Westinghouse Hanford Company - \#197)

Page : 1

File : RFLEADE.MSH

Run date: March 20, 1996

Run time: $1: 34$ p.m.
File Ref: SHLDANL1.OUT

Date: $03 / 20 / 96$

By: DWH

Checked:

CASE: R-F Lead Column from End (Eluted R-F at 0.036 Ci Cs-137)

GEOMETRY 10: Cylindrical source from end - slab shields

Distance to detector.................. X

Source cylinder radius................. $R$

Source cyl inder length............... Tl

Thickness of second shield............... T2

Microshield inserted air gap.............. air

14.910

0.750

10 .

4.9

0.010

Source Volume: 17.6715 cubic centimeters

MATERIAL DENSITIES $(\mathrm{g} / \mathrm{cc})$ :

\begin{tabular}{|c|c|c|c|}
\hline Material & Source & Shield 2 & Air gap \\
\hline Air & $----\cdots$ & $-\cdots-n$ & .001220 \\
\hline Aluminum & & & \\
\hline Carbon & & & \\
\hline Concrete & & & \\
\hline Hydrogen & & & \\
\hline Iron & & & \\
\hline Lead & & 11.30 & \\
\hline Lithium & & & \\
\hline Nickel & & & \\
\hline$T$ in & & & \\
\hline Titanium & & & \\
\hline Tungsten & & & \\
\hline Urania & & & \\
\hline Uranium & & & \\
\hline Water & 1.0 & & \\
\hline
\end{tabular}


BUILDUP FACTOR: based on BERGER method. Using the characteristics of lead.

\section{INTEGRATION PARAMETERS:}

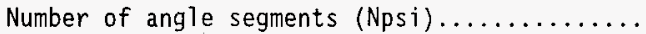
5

Number of radial segments (Nradius)...........

SOURCE NUCLIDES:

\begin{tabular}{llllll} 
Nuclide & \multicolumn{1}{c}{ Curies } & Nuclide & Curies & Nuclide & Curies \\
\hdashline Ba-137m & $3.4364 \mathrm{e}-02$ & Co-60 & $1.0960 \mathrm{e}-06$ & Cs-134 & $1.6994 \mathrm{e}-05$ \\
$\mathrm{Cs}-135$ & $2.0400 \mathrm{e}-07$ & $\mathrm{Cs}-137$ & $3.6326 \mathrm{e}-02$ & Np-237 & $1.7280 \mathrm{e}-07$ \\
$\mathrm{Pu}-239$ & $9.1200 \mathrm{e}-08$ & Sr-90 & $7.5440 \mathrm{e}-05$ & Y-90 & $7.5440 \mathrm{e}-05$
\end{tabular}

RESULTS:

\begin{tabular}{|c|c|c|c|c|}
\hline$\underset{\#}{\text { Group }}$ & $\begin{array}{l}\text { Energy } \\
(\mathrm{MeV})\end{array}$ & $\begin{array}{c}\text { Activity } \\
\text { (photons/sec) }\end{array}$ & $\begin{array}{l}\text { Dose point flux } \\
\mathrm{MeV} /(\mathrm{sq} \mathrm{cm}) / \mathrm{sec}\end{array}$ & $\begin{array}{c}\text { Dose rate } \\
(\mathrm{mr} / \mathrm{hr})\end{array}$ \\
\hline $\begin{array}{r}1 \\
2 \\
3 \\
4 \\
5 \\
6 \\
7 \\
8 \\
9 \\
10 \\
11 \\
12 \\
13 \\
14 \\
15 \\
16 \\
17 \\
18 \\
19 \\
20\end{array}$ & $\begin{array}{r}1.2670 \\
1.0391 \\
.6641 \\
.5016 \\
.5703 \\
.4766 \\
.2734 \\
.2021 \\
.1580 \\
.1038\end{array}$ & $\begin{array}{l}1.115 \mathrm{e}+05 \\
6.288 \mathrm{e}+03 \\
1.145 \mathrm{e}+09 \\
6.137 \mathrm{e}+05 \\
1.497 \mathrm{e}+05 \\
9.180 \mathrm{e}+03 \\
2.226 \mathrm{e}+02 \\
2.368 \mathrm{e}+01 \\
1.095 \mathrm{e}+02 \\
8.889 \mathrm{e}+01\end{array}$ & $\begin{array}{l}9.914 e+00 \\
2.926 e-01 \\
3.493 e+03 \\
9.310 e-01 \\
1.207 e-01 \\
6.700 e-04 \\
1.462 e-14 \\
1.639 e-25 \\
5.081 e-45 \\
0.000 e+00\end{array}$ & $\begin{array}{l}1.811 \mathrm{e}-02 \\
5.602 \mathrm{e}-04 \\
7.243 \mathrm{e}+00 \\
1.926 \mathrm{e}-03 \\
2.488 \mathrm{e}-04 \\
1.367 \mathrm{e}-06 \\
2.900 \mathrm{e}-17 \\
3.029 \mathrm{e}-28 \\
8.874 \mathrm{e}-48 \\
0.000 \mathrm{e}+00\end{array}$ \\
\hline & OTALS: & $1.146 \mathrm{e}+09$ & $3.504 \mathrm{e}+03$ & $7.264 e+00$ \\
\hline
\end{tabular}




\section{MICROSHIELD BATCH RUN LOG}

Batch run started on Wednesday, March 20, 1996 at 1:33 p.m.

Eight files initially in the queue.

\begin{tabular}{|c|c|c|c|c|c|c|}
\hline CASE & FILE & START TIME & ELAPSED & GEOM & DOSE $(\mathrm{mr} / \mathrm{hr})$ & SENS. CYCLE \\
\hline$===$ & $= \pm== \pm====$ & $=== \pm== \pm= \pm==$ & $=======$ & $===$ & $== \pm==0$ & \\
\hline $\begin{array}{l}1 \\
2 \\
3 \\
4 \\
5 \\
6 \\
7 \\
8\end{array}$ & $\begin{array}{l}\text { DSSFSMPI } \\
\text { DSSFSMPE } \\
\text { CSTLEAD } \\
\text { CSTLEADE } \\
\text { CSTGRD } \\
\text { CSTGRDE } \\
\text { RFLEAD } \\
\text { RFLEADE }\end{array}$ & $\begin{array}{l}1: 33 \text { p.m. } \\
1: 33 \text { p.m. } \\
1: 34 \text { p.m. } \\
1: 34 \text { p.m. } \\
1: 34 \text { p.m. } \\
1: 34 \text { p.m. } \\
1: 34 \text { p.m. } \\
1: 34 \text { p.m. }\end{array}$ & $\begin{array}{l}0: 00: 12 \\
0: 00: 02 \\
0: 00: 08 \\
0: 00: 02 \\
0: 00: 08 \\
0: 00: 02 \\
0: 00: 08 \\
0: 00: 02\end{array}$ & $\begin{array}{r}7 \\
10 \\
7 \\
10 \\
7 \\
10 \\
7 \\
10\end{array}$ & $\begin{array}{l}7.3259 \mathrm{e}+00 \\
8.0739 \mathrm{e}+00 \\
8.5983 \mathrm{e}+00 \\
6.8424 \mathrm{e}+00 \\
9.4378 \mathrm{e}+00 \\
7.4923 \mathrm{e}+00 \\
8.9727 \mathrm{e}+00 \\
7.2641 \mathrm{e}+00\end{array}$ & $\begin{array}{l}(n / a) \\
(n / a) \\
(n / a) \\
(n / a) \\
(n / a) \\
(n / a) \\
(n / a) \\
(n / a)\end{array}$ \\
\hline
\end{tabular}

Batch run completed on Wednesday, March 20, 1996 at 1:34 p.m. TOTAL EXECUTION TIME: 0:00:59 
Microshield 3.12

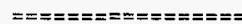

File : DSSFTRTI.MSH

Run date: March 21, 1996

Run time: $11: 19$ a.m.

(Westinghouse Hanford Company - \#197)

CASE: 101AW Effluent 01000 CS DF, $100 \mathrm{~mL}$ Sample Bottle

GEOMETRY 7: Cylindrical source from side - cylindrical shields

Distance to detector.................

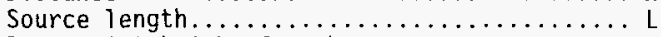

Dose point height from base............. Y

Source cylinder radius.................. TI

Thickness of second shield................ T2

Microshield inserted air gap.............. air

2.510

8.

4.

2 .

0.5

0.010

Date: $\frac{03 / 21 / 96}{0.06}$

By: $\overline{D W H}$

Checked:

Source Volume: 100.531 cubic centimeters

MATERIAL DENSITIES $(\mathrm{g} / \mathrm{cc})$ :

\begin{tabular}{lccc} 
Material & Source & Shield 2 & Air gap \\
\hline Air & & & .001220 \\
Aluminum & & & \\
Carbon & & & \\
Concrete & & & \\
Hydrogen & & \\
Iron & & 11.30 & \\
Lead & &. \\
Lithium & & \\
Nicke1 & & \\
Tin & \\
Titanium & & \\
Tungsten & & \\
Urania & & \\
Uranium & & \\
Water & & \\
Zirconium & 1.0 &
\end{tabular}


CASE: 101AW Effluent 01000 CS DF, $100 \mathrm{~mL}$ Sample Bottle

BUILDUP FACTOR: based on BERGER method. Using the characteristics of lead.

\section{INTEGRATION PARAMETERS:}

Number of lateral angle segments (Ntheta).... 5

Number of azimuthal angle segments (Npsi)..... 5

Number of radial segments (Nradius)........... 5

\section{SOURCE NUCLIDES:}

\begin{tabular}{|c|c|c|c|c|c|}
\hline Nuctide & Curies & Nuclide & Curies & Nucl ide & Curies \\
\hline $\begin{array}{l}\text { Am-241 } \\
\text { Cm-243 } \\
\text { Cs }-135 \\
\text { I-129 } \\
\text { Pu-239 } \\
\text { Sr-90 }\end{array}$ & $\begin{array}{l}5.9500 \mathrm{e}-06 \\
2.3150 \mathrm{e}-09 \\
1.2750 \mathrm{e}-10 \\
1.5150 \mathrm{e}-08 \\
5.7000 \mathrm{e}-08 \\
4.7150 \mathrm{e}-05\end{array}$ & $\begin{array}{l}\mathrm{Ba}-137 \mathrm{~m} \\
\mathrm{Co}-60 \\
\mathrm{Cs}-137 \\
\mathrm{Nb}-94 \\
\mathrm{Ru}-105 \\
\mathrm{Tc}-99\end{array}$ & $\begin{array}{l}2.1479 \mathrm{e}-05 \\
6.8500 \mathrm{e}-07 \\
2.2705 \mathrm{e}-05 \\
3.4100 \mathrm{e}-06 \\
3.4110 \mathrm{e}-05 \\
7.6000 \mathrm{e}-06\end{array}$ & $\begin{array}{l}C-14 \\
C s-134 \\
H-3 \\
N p-237 \\
S e-79 \\
Y-90\end{array}$ & $\begin{array}{l}1.8500 \mathrm{e}-08 \\
1.0622 \mathrm{e}-08 \\
2.5400 \mathrm{e}-07 \\
1.0800 \mathrm{e}-07 \\
2.4000 \mathrm{e}-08 \\
4.7150 \mathrm{e}-05\end{array}$ \\
\hline
\end{tabular}

RESULTS:

\begin{tabular}{|c|c|c|c|c|}
\hline$\underset{\#}{\text { Group }}$ & $\begin{array}{l}\text { Energy } \\
(\mathrm{MeV})\end{array}$ & $\begin{array}{c}\text { Activity } \\
\text { (photons/sec) }\end{array}$ & $\begin{array}{l}\text { Dose point flux } \\
\mathrm{MeV} /(\mathrm{sq} \mathrm{cm}) / \mathrm{sec}\end{array}$ & $\begin{array}{c}\text { Dose rate } \\
(\mathrm{mr} / \mathrm{hr})\end{array}$ \\
\hline $\begin{array}{r}1 \\
2 \\
3 \\
4 \\
5 \\
6 \\
7 \\
8 \\
9 \\
10 \\
11 \\
12 \\
13 \\
14 \\
15 \\
16 \\
17 \\
18 \\
19 \\
20\end{array}$ & $\begin{array}{l}1.2578 \\
.8672 \\
.6688 \\
.5954 \\
.4766 \\
.2891 \\
.2534 \\
.2035 \\
.1580 \\
.1047\end{array}$ & $\begin{array}{l}5.071 \mathrm{e}+04 \\
1.262 \mathrm{e}+05 \\
8.416 \mathrm{e}+05 \\
4.772 \mathrm{e}+02 \\
5.738 \mathrm{e}+00 \\
6.238 \mathrm{e}-01 \\
2.125 \mathrm{e}+01 \\
1.762 \mathrm{e}+01 \\
6.871 \mathrm{e}+01 \\
8.471 \mathrm{e}+01\end{array}$ & $\begin{array}{l}3.615 \mathrm{e}+02 \\
5.146 \mathrm{e}+02 \\
2.072 \mathrm{e}+03 \\
9.297 \mathrm{e}-01 \\
5.979 \mathrm{e}-03 \\
5.255 \mathrm{e}-05 \\
4.100 \mathrm{e}-04 \\
4.369 \mathrm{e}-05 \\
9.088 \mathrm{e}-07 \\
2.636 \mathrm{e}-09\end{array}$ & $\begin{array}{l}6.614 \mathrm{e}-01 \\
1.021 \mathrm{e}+00 \\
4.291 \mathrm{e}+00 \\
1.922 \mathrm{e}-03 \\
1.220 \mathrm{e}-05 \\
1.051 \mathrm{e}-07 \\
8.049 \mathrm{e}-07 \\
8.093 \mathrm{e}-08 \\
1.587 \mathrm{e}-09 \\
4.011 \mathrm{e}-12\end{array}$ \\
\hline & OTALS: & $1.019 \mathrm{e}+06$ & $2.949 e+03$ & $5.975 e+00$ \\
\hline
\end{tabular}




\section{DISTRIBUTION SHEET}

\begin{tabular}{|c|c|c|c|c|c|}
\hline \multirow{2}{*}{$\begin{array}{l}\text { To } \\
\text { Distribution }\end{array}$} & \multirow{2}{*}{\multicolumn{2}{|c|}{$\begin{array}{l}\text { From } \\
\text { ETTP/PE }\end{array}$}} & & \multicolumn{2}{|c|}{ Page 1 of 1} \\
\hline & & & & \multicolumn{2}{|c|}{ Date $05 / 31 / 96$} \\
\hline \multicolumn{4}{|l|}{ Project Title/Work Order } & \multicolumn{2}{|c|}{ EDT No. 611413} \\
\hline Hanford Tank Waste Supe & esium Removal & est Plan & & \multicolumn{2}{|c|}{ ECN No. } \\
\hline Name & MSIN & $\begin{array}{c}\text { Text } \\
\text { With All } \\
\text { Attach. }\end{array}$ & Text Only & $\begin{array}{l}\text { Attach./ } \\
\text { Appendix } \\
\text { Only }\end{array}$ & $\begin{array}{c}\text { EDT/ECN } \\
\text { Only }\end{array}$ \\
\hline
\end{tabular}

Akita, R.

Appe 1, J. N.

Beck, M.A.

Benar, C. J.

Berger, J.D.

Brown, G.N.

Brown, L. C.

Duncan, J. B. (4)

Eberlein, S. J.

Edmondson, D. W.

Hall, M. J.

Hendrickson, D. W. (8)

Herting, D. L.

Hunter, J.A.

Hyatt, J. E.

Kurath, D.E.

Jewett, J.R.

Jaten, K.H.

Klem, M.J.

Lamson, S. B.

McDonald, G. T.

Narquis, C. T.

Smith, J. R.

Stewart, $T$.

TCRC (2)

Voogd, J. A.

Central files (orig +2 )

DPC
T6-20

G3-21

T6-09

R2-12

$\mathrm{H} 6-34$

P7 -25

L5-62

L5-55

R2-12

T6-09

$\mathrm{T} 6-12$

L5-31

T6-09

L5-31

S3-31

P7-20

T6-09

T6-04

H5-27

T6-28

$\lfloor 5-31$

T6-16

T6-09

K9-91

R2- 12

H5- 03

A3-88

A3-94

$x$
$x$
$x$
$x$
$x$
$x$
$x$
$x$
$x$
$x$
$x$
$x$
$x$
$x$
$x$
$x$
$x$
$x$
$x$
$x$
$x$
$x$
$x$
$x$
$x$
$x$
$x$
$x$

